\title{
A Review on Factors Influencing the Mismatch Losses in Solar Photovoltaic System
}

\author{
A. D. Dhass $\mathbb{D}^{1},{ }^{1}$ N. Beemkumar $\left(\mathbb{D},{ }^{2}\right.$ S. Harikrishnan $\left(\mathbb{D},{ }^{3}\right.$ and Hafiz Muhammad Ali ${ }^{4}{ }^{4}$ \\ ${ }^{1}$ Department of Mechanical Engineering, IITE, Indus University, Ahmedabad 382115, India \\ ${ }^{2}$ Department of Mechanical Engineering, FET, Jain (Deemed to Be University), Bengaluru 562112, India \\ ${ }^{3}$ Department of Mechanical Engineering, Kings Engineering College, Sriperumbudur 602117, India \\ ${ }^{4}$ Mechanical Engineering Department, King Fahd University of Petroleum and Minerals, Dhahran 31261, Saudi Arabia
}

Correspondence should be addressed to Hafiz Muhammad Ali; hafiz.ali@kfupm.edu.sa

Received 8 October 2021; Revised 9 January 2022; Accepted 1 February 2022; Published 14 February 2022

Academic Editor: Alberto Álvarez-Gallegos

Copyright (c) 2022 A. D. Dhass et al. This is an open access article distributed under the Creative Commons Attribution License, which permits unrestricted use, distribution, and reproduction in any medium, provided the original work is properly cited.

In the last two decades, it is persistently emphasized to develop energy generation systems free from greenhouse gas emissions since these gases cause global warming, and it leads to unpredictable monsoons. Consequently, it might not be a conducive environment for human beings and animals to dwell. To ascertain the green environment for the next generations and reduce the use of fossil fuels, renewable energy sources are highly suggested to generate electrical energy. Solar photovoltaic is reckoned to be one of the promising methods to generate electricity; however, it has a lower conversion value due to various losses resulting from external and internal parameters. Among various losses that occurred in the solar photovoltaic system, mismatch loss is imperative, which causes the system to perform poorly. Solar photovoltaic systems have made topical advances in the use of highly effective solar cell materials to achieve high efficiency. In this analysis, performance parameters are influenced by the internal and external conditions of the solar photovoltaic systems and they lead to an increase in the loss of the system. The present review is focused to fetch fruitful information on the several studies that analyzed the effects on the solar photovoltaic systems of parasitic resistances, dust generated by tresses, clouds, solar radiation, temperature, relative humidity, different connection topologies, circuit implementation for partial shading, and remedies suggested by the potential authors.

\section{Introduction}

The conversion efficiency of the solar photovoltaic (SPV) devices can also be improved by minimizing mismatch, temperature, and ohmic losses. Based on the availability of incident solar radiation, the mismatch effect can be reduced by adding an appropriate connection configuration. The SPV cell equivalent circuits consisting of parasitic resistance (shunt and series resistance) should be taken into account to obtain the high performance of devices. To reduce the leakage current, the series resistance is as low as possible, and the shunt resistance should be optimal to ensure that the current passes through the external load. The SPV cell's temperature increases the current flow to the uniform solar radiation and decreases the current flow and produces a hotspot when partial shading and different solar radiation fea- tures are associated with an SPV cell. Effects of mismatch and outdoor conditions should be held to a limited standard and correct chosen connection topologies. For high power output in an SPV cell, appropriate circuit equivalent values and appropriate SPV-cell materials are selected based on the use of solar radiation. In general, prominent SPV cell materials like monocrystalline and polycrystalline silicon ( $\mathrm{m}$-Si and $\mathrm{p}-\mathrm{Si}$ ), SPV-based materials have a high fill factor and conversion efficiency [1-3].

The increasing number of photovoltaic plants throughout the world in recent decades has exposed deviation in estimated and actual photovoltaic energy generation. This deviation is due to power losses, more often called mismatch losses, which can be defined as the difference between the maximum power of each array module and the power of the complete SPV plant. The module is mainly distorted by 
two factors: the dispersion of electrical properties and the partial illumination of the SPV cell. The SPV panels transform directly solar energy into thermal and electricity. Solar energy is a crucial factor in constructing additional SPV systems (electric and thermal) to meet supply demands, dramatically reducing the energy crisis. SPV's performance is based on the power converter and the characteristic specification of an SPV cell by solar energy. For example, a device's conversion efficiency can be improved by reducing the amount of energy lost due to mismatch and temperature variations. Incompatible losses are caused by partial shading and variations in SPV cell parameters [4].

Solar radiation creates a hotspot, in the presence of partial shading, which raises device temperature. The SPV system involves dissymmetric gathering, the decaying module layer and the potential break-up of the cell, the accumulation of dust particles in the modules, and unequal exposure to the solar radiation in the modules [5]. Many researchers have made some new developments to enhance energy efficiency such that power losses and incongruity in SPV systems can be minimized at the same time. Increased losses are calculated using two methods: (1) the comparison between the ideal and maximum SPV value and (2) the application of calculating losses by Bucciarelli equations. Incompatible losses in fresh and old SPV cells are calculated using Bucciarelli equations. In general, low $(<0.01 \%)$ losses were observed for fresh SPV cells and high $(>10 \%)$ in aging SPV cells. The integrated bypass diode is added to minimize SPV module errors, parallel connections are selected, and shunt resistance is reduced [6].

An SPV system uses various methods to avoid mismatch losses. The passing clouds were blocking the incident of solar radiation on the surface of SPV, causing partial shading of the SPV module and the proxy maximum power point (MPP) monitoring rather than the actual MPP. The available solar radiation creates a hotspot in the SPV module. To overcome this issue, all the connecting modules, the Total Cross Tied (TCT) connection provided the maximum output and fill factor, with low power losses in the SPV module, as compared with the simple series (SS), series-parallel (SP), honeycomb (HC), and bridge link (BL). Incompatibility caused a $4.8 \%$ loss of electrical shading due to partial shading. By implementing correct connections and sorting various modules, this problem can be solved. With reconnection topology, insufficient losses in uniform solar radiation are reduced and the power efficiency of the $3 \mathrm{~kW} \mathrm{SPV}$ system increases by $22.4 \%$ by an interval of 1 minute $[7,8]$.

Dynamic reconfiguration and Sudoku constructions can help to minimize losses in the SPV system without altering TCT connections. A Sudoku automatic method is also implemented to minimize wire losses in an SPV system that reduces partial shade losses significantly [9]. Mismatch losses are due to electrolightning, infrared imaging, current voltages (I-V), and a wide-range laser-beam scan. Based on these data, the effectiveness of SPV cells is easily assessed [10].

The power output of the SPV module is determined by selecting the correct crystalline material. Equivalent to a single diode circuit, the two- and three-diode SPV cells are also ideally suited to high solar radiation conditions. Likewise, crystalline Si materials are two types of monocrystalline silicon $(\mathrm{m}-\mathrm{Si})$ and polycrystalline $(\mathrm{p}-\mathrm{Si})$ materials producing a higher production potential than $\mathrm{m}$-Si in the dry environment. A comparative analysis with $\mathrm{m}-\mathrm{Si}$ and $\mathrm{p}-\mathrm{Si} \mathrm{SPV}$ with an equivalent power rating is performed in dry weather conditions, and the final average annual potential is achieved by 5.24 and $5.38 \mathrm{kWh}$ per day [11].

The $\mathrm{p}$-Si-based modules, with the thin film providing the best performance, and the cadmium telluride- (CdTe-) and copper indium gallium selenide- (CIGS-) based modules provide significant electrical energy generation. Similar SPV materials are suitable for different weather requirements [12]. In nonhomogenous conditions, it has special SPV array MPPs to set the device with a shadow factor. Various connection schemes (SS, SP, BL, HC, and TCT) were implemented, and one important part of the TCT relationship is the resolution of this problem [13]. By using the Lambert-W function in MATLAB and mathematical equations, the simple exponent and nonlinear SPV equations (Bucciarelli equations) were facilitated [14]. The optimum value of SPV is performed, and a voltage regulator is used to reduce SPV losses during sunny and nonsunny days [15].

Figure 1 shows the research studies starting the period from 2001, in which different mismatch loss values were used to explore the behavior and characterization aspects of photovoltaic systems. Over the past decade, the use of SPV systems has increased, but the issues and shortages related to these systems have become more important. Thus, the number of scientific studies utilizing the photovoltaic influence of internal and exterior factors has significantly expanded, particularly after 2013. Photovoltaic system analysis, taking into account mismatch loss parameters, is emphasized throughout the study. Accordingly, thorough reviews are needed to assess the current situation and give a roadmap for future scientific endeavors under these conditions.

Previous studies have shown improvements in the efficiency of the SPV network through enhanced network connections, the addition of bypass diodes, various internal parameters, selection of suitable places, and periodic system support. The Bucciarelli equations on analog SPV cell circuits and simulation methods support these findings in theory. By comparison, it reduces device efficiency by adding additional components to the SPV unit as it absorbs considerable power from various processes. In this review article, the insufficient loss caused by different factors is considered. The key criteria for an investigation into the mismatch loss of solar photovoltaic systems (SPVs), internal and external parameter impact, system losses, and causes of inconsistent losses in solar power systems are established. For the analysis of solar photovoltaic systems, students, researchers, members, and decision-making personnel, this paper is valuable. This will be useful in improving SPV systems, engineers, scientists, generators, and policymakers. The purpose of this review is to present a comprehensive description of the influence of internal and external parameters, mismatch losses, causes of mismatch losses (solar radiation, temperature, dust, and relative humidity), different topological 


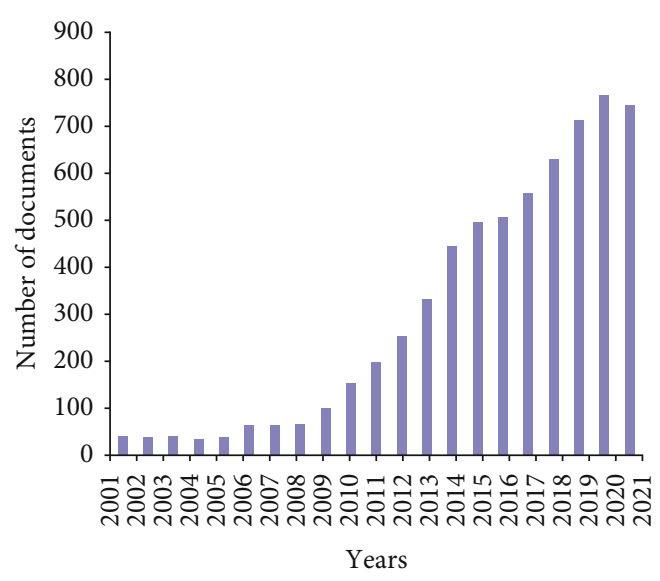

Figure 1: Studies on mismatch losses in the solar photovoltaic systems since 2001 .

connections, and the merits and demerits of the solar photovoltaic system.

\section{Review on Mismatch Losses}

In recent years, the amount of electricity generated from renewable sources has outpaced that generated from conventional sources. In particular in remote areas, this will bridge the gap between energy demand and the end-user supply. Solar conversion is the most efficient way to produce electric and thermal energy. Electric energy is used for domestic and commercial purposes while thermal energy uses industrial applications such as chemical processing. As a result, most scientists have tried to establish effective electricity generation methods. Studies focused primarily on solar energy photovoltaics by either increasing the power generation or reducing photovoltaic energy losses. Highly effective SPV materials can be used for performance enhancement.

Further partial shading losses and changes to SPV cell parameters lead to degradation of the SPV system's performance. Several studies have been performed to increase the processing power, such as comparable circuit parameters, reliable topological relationship regimes, and temperature effects. The system efficiency can be enhanced by maximum parasitic resistance, and the effect of shadow and temperature is under control.

\subsection{Classification of Solar Photovoltaic (SPV) Materials.} Inorganic or organic materials transform the SPV cell into high-quality electricity incidents caused by solar radiation. Figure 2 outlines the different practical SPV materials [16]. The materials of $\mathrm{c}-\mathrm{Si}$ are mainly divided into $\mathrm{m}-\mathrm{Si}$ and $\mathrm{p}-\mathrm{Si}$ materials by manufacturing technologies. In an arsenide matrix, the photovoltaic material Gallium Arsenide (GaAs) is formed. Depending on the environment, the output of $\mathrm{p}-\mathrm{Si}$ is ideal for hot climatic conditions, and $\mathrm{m}-\mathrm{Si}$ and $\mathrm{GaAs}$ can work in normal conditions. GaAs provide the best performance in photovoltaic cells among these crystalline materials.
Since material from Si was not available today, SPV thinfilm cells were used in the manufacture of thin-film SPV cells, which reduced the cost of production of crystalline SPV cells by up to $50 \%$. The difference between supply and demand has been reduced to the lowest possible level by the use of, for example, [Si-based] and chalcogenide-based SPV cells (cadmium sulfides and cadmium tellurides (CdTe) and copper-indium diselenides) of different SPV cells such as $\mathrm{Si}$ (solitary, amorphous $\mathrm{Si}$, and glass) [17].

Thin-film material is having bandgap $(1.52 \mathrm{eV})$ with high open-circuit voltage, and short-circuit current density was evaluated for the performance of bulk heterojoint solar cells based on polymer (naphthobisoxadiazole) [18]. Optical control and systems for high-performance hybrid solar thinfilm cells, which use amorphous $\mathrm{Si}$ or organic solar cells, achieve $10.5 \%$ [19].

This hybrid SPV cell was cheaper and less weighty than other equipment. The basic conduct and values of SPV cell type, namely, color-sensitive SPV cells, are examined to convert solar radiation with photoelectrochemical processes into electric energy [20].

Implementations of SPV systems can be categorized as active and passive, as shown in Figure 3 [16]. In the active systems, electrical or mechanical equipment converts incident solar radiation in the SPV system into a DC source of power or thermal power. The high-quality electrical power is provided by an SPV module, which in comparison to other solar energy sources can be stored in large quantities. SPV panels of various materials, such as crystalline $\mathrm{Si}$, thin film-based materials, and organic materials, can be used for high-performance processing materials. Solar radiation is transferred into heat energy directly in a passive unit, without the use of mechanical or electrical equipment (solar chimney and solar oven).

When solar radiation is lesser than the norms $(1000 \mathrm{~W} /$ $\mathrm{m}^{2}$ ) and the entire cell area is unable to take the same volume, a hot spot inside the system is created that contributes to the failure of the system. The SPV cell current is normally equal to the volume of solar radiation. However, this effect cannot be accomplished in an SPV cell, since only a proportion of the solar radiation incident is transferred into power and the remained heat dissipates; the actual output is measured using a temperature coefficient. Moreover, efficiency decreases as the cell's temperature increases.

The DC energy output causes ohmic loss because of the different resistors of cable and connector connections. To lower shadow loss and block the current flux of the system, the diode is connected to an SPV system. Climate conditions and material degradation have been reported as causing failure in the SPV module. Depending on the construction site, the climatic conditions on the surface of a module include solar radiation, ultraviolet rays, wind, snow, rain, frost, low and high temperatures, salt, sand, and dust [21]. Also essential in improving power loss and reducing the operation time of the SPV module is the material degradation mechanism.

2.2. Current-Voltage Characteristic Curve. Mismatch losses are induced in series and parallel configurations of the combined SPV modules by variations in the current-voltage (I- 


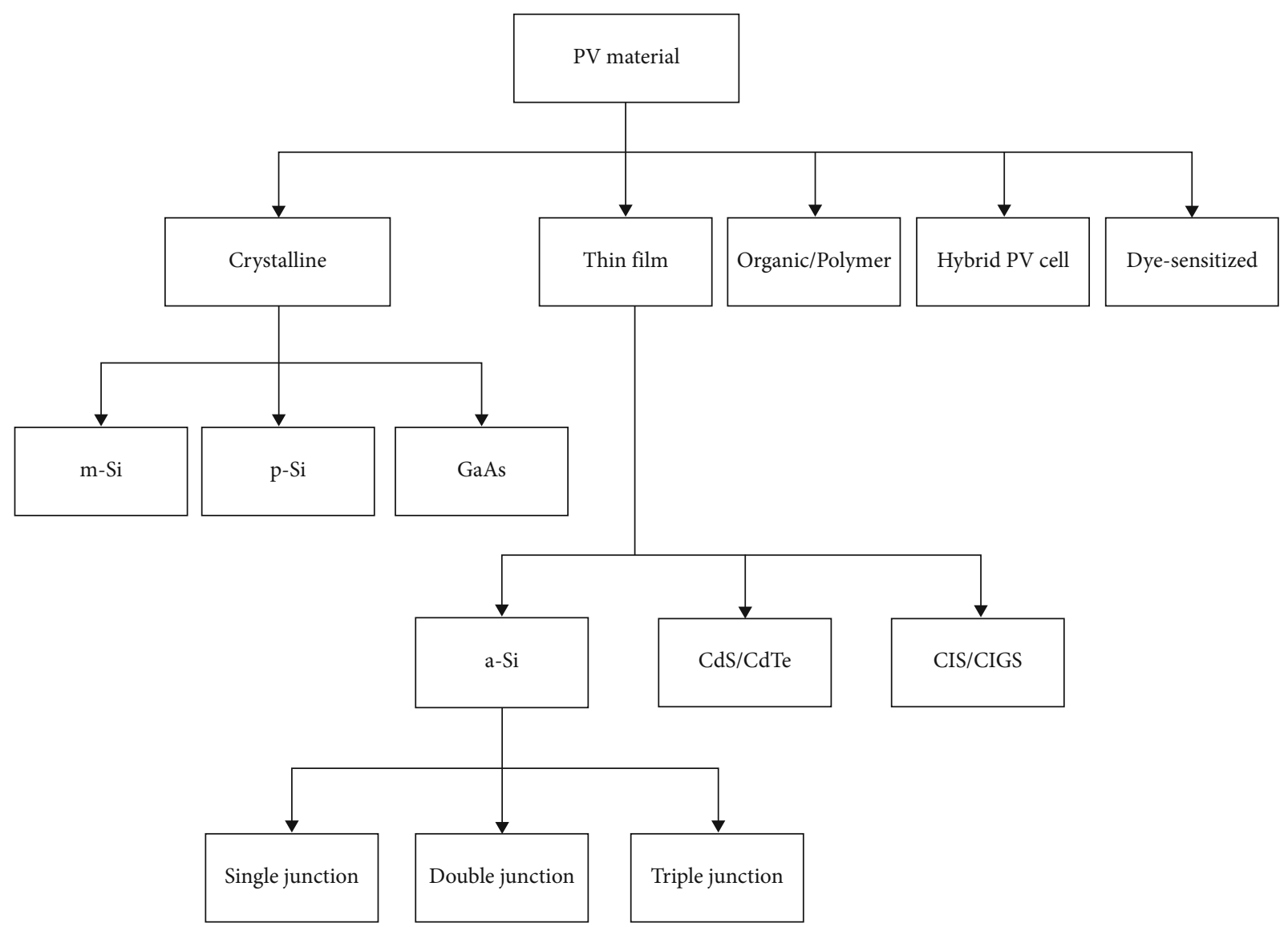

FIGURE 2: Classification of SPV materials [16].

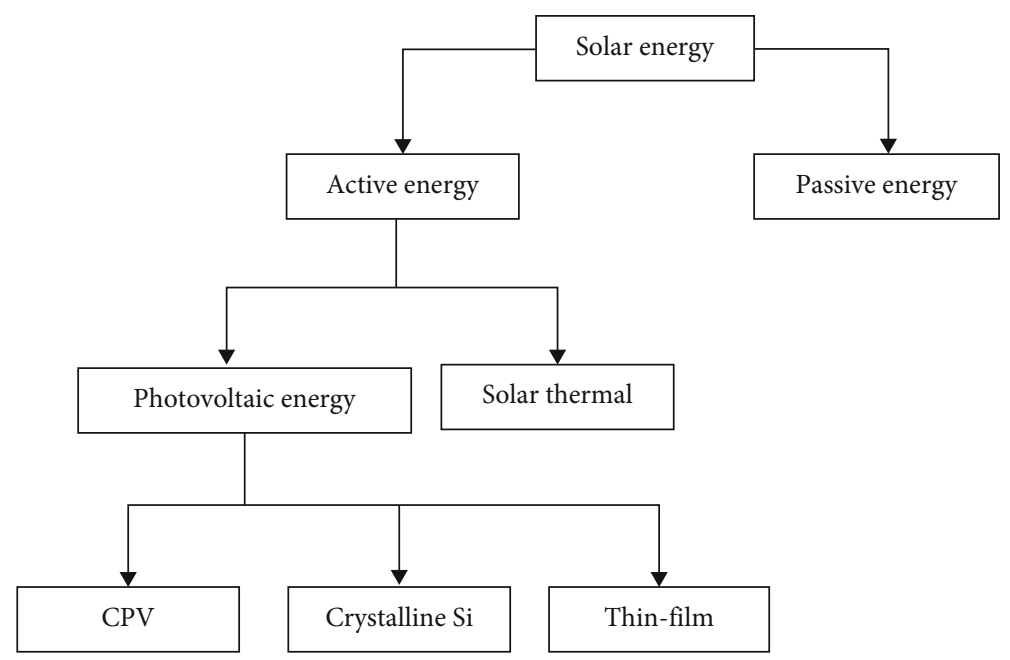

Figure 3: Classification of SPV materials based on SPV applications [16].

V) properties, voltage and current inconsistencies, and lower partial shading. The current output of SPV modules decreased $80 \%$ of the actual power output for two decades [22]. The presence of dust, moving nukes, and shadows in solar panels is an obstacle that minimizes incidents of solar radiation. The shadow area in the SPV module decreases current and functions as a terminal load, generating a hot spot on SPV as opposed to the rest of not affected area. Thus, the short-circuit current is adjusted and minor changes in fill factor and efficiency in the SPV module are prominent [23].

The average production decrease of $10.22 \%, 10.39 \%$, $9.62 \%$, and $8.70 \%$ for SPV modules, respectively, was induced when dust particles were deposited per month and per day [24]. The performance and efficiency of the SPV system are affected by overall parameters, such as shading effect, dust removal, operating temperature, and solar angle 
tracking systems [25]. We investigate the role of solar radiance, thermal orientation, tilt angle, shadowing, and poisoning by reducing SPV module output parameters. Photovoltaic soiling modules have a degrading effect; cleaner, optimized technology is more energizing than clean technology [26]. In addition, in Kuwait, over 12 months, total land losses of $45 \%$ and $42 \%$ are reported in clean water technology, respectively, for Azda and Sawda [27]. Without SPV module cleaning, the SPV system production decreases by up to $1 \%$ daily. The implementation of a two-axis tracking device on the SPV module also provides solar radiation to boost its output parameters [28]. SPV performance and other factors including nominal plate details, losses in the diode and connection, loss of mismatch, the DC, the AC cable, sun-tracking losses, shading losses, and soil loss were adjusted due to solar radiation incidents and cell temperature [29].

For the precision and degradation factors of the SPV modules, a reliability model is used. The performance of the SPV module reduces the deterioration of packaging materials, cell/module relation, humidity intrusion, semiconductors, and lost encapsulation bonding [30]. The effect of dust is calculated on the surface of SPV monocrystalline and polycrystalline modules, and maximum power losses or losses of current were shown to be between $18 \%$ and $78 \%$ and between $23 \%$ and $80 \%$. The deposition of dust does not affect open-circuit voltage or maximum voltages. The general characteristics of $\mathrm{I}-\mathrm{V}$ and powervoltage $(\mathrm{P}-\mathrm{V})$ are also different from the current curve of the SPV modules [31].

A new theoretical model for the performance parameters of SPV modules/streams/arrays has been developed with MATLAB. This model data is used to check the model precision and viability of the effects of other software simulation models (INSEL and PVsyst) [32]. Measurements of the simulated model are compared to test measurements on a network of grid-connected SPVs. The results of the model matched experimental values because of the effect of the SPV soiling, aging, and deterioration system on the real weather conditions. A new model was developed to estimate the high accuracy and low approximation of SPV cell failure in one diode consisting of series and parallel bypass and blocking diodes [33].

A pattern search technique categorizes problems with SPV cell parameters. This method is used to evaluate a two-diode model's output which gives the actual measured data better results [34]. For a single circuit in a MATLAB Simulink, mathematical models are built that also analyze the effect on three points, namely, open-circuit voltage, high power, and short-circuit current of the external (solar and temperature) parameters and internal (shunt and series resistance) parameters [35].

In different solar radiation and temperature, the dynamical resistance and the MPP values of the SPV modules are measured with the aid of a direct measurement system. The findings of this study closely correlate with the experimental dynamic values of the SPV module [36]. The shunt resistors of each cell are determined without electrical connection estimation. In a-Si, the voltage, fill factor, and effi- ciency of the individual cell will steadily improve as the shunt resistance increases [37].

2.3. Effects of Internal Parameters. A new partial shade technology, with two different shade ratios consisting of a qualifying test, the accelerated lifetime test, and a long-term I$\mathrm{V}$ characteristic test, enumerates the resistance of individual cells to the sequence. The results of the simulation are compared to the tests for improving controlled performance [38]. The effect of shunt resistance on an SPV crystalline panel on the solar radiation incident is analyzed. The reverse I-V curve determines the shunt resistance of dark light illuminations and shows the reverse dependency on the shunt resistance of incident solar radiation [39].

A single circuit equivalent to a single diode of the solar cell consists of five internal and external factors which influence the performance of a solar cell. Solar radiation variables and external conditions affect the photogenic rating current and the reverse saturation current in the diode ideality, sequence, and resistances. Moreover, the internal parameters necessary to achieve the highly accurate performance of the solar cell should be selected and properly managed [40].

The shunt and series resistance values of an explicit model are contrasted with the experimental values obtained from the SPV module [41]. The Newton-Raphson method measures the shunt parameters and series resistance values and simplifies the Lambert $\mathrm{W}$ function of the equations. The values are measured in 3 light conditions $\left(800,900\right.$, and $\left.1000 \mathrm{~W} / \mathrm{m}^{2}\right)$ and checked for the root mean square error analysis to be correctly accurate $[42,43]$. These two analytical methods have been compared with experimental short-circuit current data, opencircuit voltage and maximum power point current, and maximum power point voltage [44].

For optimal performance, the resistance values in an SPV cell are calculated on the basis that SPV cell materials have size, shape, and properties [45]. A functional SPV circuit equivalent model takes into account the series resistance of a Si-based SPV cell on each connection area and electrode. In the case of leakage, the current flow through an SPV cell can be reduced due to a defect in the SPV cell structure by introducing a parallel shunt resistance across the P-N junction diode. Microstructure analysis of the polycrystalline photovoltaic lead $\mathrm{SnAgPb}$ is performed [46].

A photovoltaic system algorithm is used to estimate current and power in appalling conditions. The proposed algorithm discusses the SPV field, diode blocking, and the bypass diode in sequence and parallel resistance. The Lambert $\mathrm{W}$ feature simplifies the explicit I-V characteristic equation. The results show that the relative average SPV power mistake has dropped by $50 \%$. It can be used for other SPV cells such as polycrystalline, thin films, and organically dependent cells [47].

The solar cell temperature, the backside temperature, the atmospheric temperature, the open-circuit voltage, the short-circuit current, the maximum point voltage, and the maximum point current are used to evaluate the thermal and electrical outputs of a photovoltaic device [48]. The Lambert $\mathrm{W}$ function for the investigation of capability I-V 


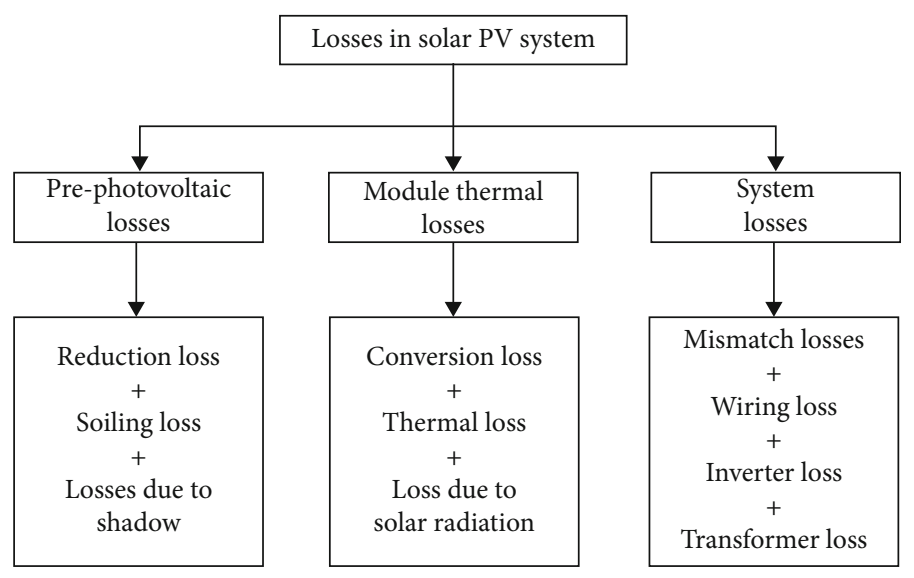

FIgURE 4: Losses associated in solar photovoltaic system [170].

and $\mathrm{P}-\mathrm{V}$ effects is applied to compare these results with those of the MATLAB simulation with the simulation outcome both curves become stronger [49].

New technology has been developed for nonlinear output parameters of a single SPV diode cell. The results are calculated using a simulation system with 2 diode model parameters [50]. A single solar cell diode is used to analyze a technology to determine the IV output parameters via the polynomial curvature fitting method and Lambert W function. This method provides good precision and fewer errors, and the typical method of adaptability is an SPV cell product [51]. The thermal activity of SPV cells based on Si and GaAs is investigated. The SPV cell is connected to high and low loads, and the system acts as a source of power and voltage. Effective methods of removal of heat, such as natural or forced flow, reduce the SPV cell temperature [52].

A thin-film cell (amorphous cell) operating in low solar radiation level is efficient material, compared with $\mathrm{m}-\mathrm{Si}$ and p-Si SPV cells. The solar cell a-Si can only be based at squat lighting rates up to $500 \mathrm{~W} / \mathrm{m}^{2}$ with $\mathrm{m}$-Si and $\mathrm{p}$-Si cells that display better efficiency at a median solar radiation rate up to $900 \mathrm{~W} / \mathrm{m}^{2}$. The conversion efficiency of low bandgap materials was reduced by more than $900 \mathrm{~W} / \mathrm{m}^{2}$ [53]. The parameters for the development of $\mathrm{m}-\mathrm{Si}$ and $\mathrm{p}-\mathrm{Si}$ panels are measured in semiarid climatic conditions on selected days and months. The open-circuit voltage, the shortcircuit current, and the conversions are related to SPV modules; the m-Si SPV module is higher and slightly lower than the p-Si SPV module [54].

The transparent and infrared areas are amorphous, polycrystalline, and monocrystalline materials, with a maximum exposure of $0.522,0.922$, and $0.704 \mu \mathrm{m}$, respectively [55]. In various research laboratories, three SPV module outputs are compared, between Sandia National and the National Norms Institute; the coefficients of temperature were up to $17 \%$, resulting in a decrease in SPV module output of less than $2 \%$. In each three-form SPV module, the relatively short-circuit current differs to $4 \%$ [56].

2.4. Effects on Output Parameters. The m-Si p-Si and a-Si solar modules are tested with a single-axis tracking device in Malaysia's hot and moist environments. The higher energy efficiency of the p-Si module was based on the degree of solar incidents. The module with the m-Si solar module has a lower and maximum solar module template [57]. In the same climate with efficiency and energy efficiency, the three SPV modules are compared. The SPV modules are $\mathrm{m}$-Si and amorphous for optimum and lowest efficiency [58].

In total, there will be 5 modules for the tracing and analysis of SPV outputs and efficiency, as well as relative quality losses (m-Si, p-Si, CIGS (copper indium gallium selenide), CIS (Copper Indium Selenide), and CdTe (Copper Telluride), the SPV modules $\mathrm{m}$-Si and CdTe (Copper Indium Telluride)). CIGS showed the complete power output of thinfilm SPV modules [12]. In degradation, temperature coefficients, and performance parameters, five SPV modules (Si1, multicrystallized Si, Si-2, CIGS, and hetero-Si film) are considered to be analyzed. The annual rates for degradation of SPV modules are approximately $0.50-4.95 \%$. The frequency of deterioration in 25 years is around $10-50 \%$. When the photovoltaic modules had an increased annual degradation rate of 5\%, the Levelized Cost of Electricity (LCOE) cost doubled [59].

With an SPV device connected to an energy-efficient charge, the full power efficiency of the SPV cannot be achieved. The battery power of the SPV network as well as weather and operating conditions is therefore critically essential for the cable thickness and the temperature and the shading mechanism, the characteristics of $\mathrm{I}-\mathrm{V}$, and inverter capacity. The input parameter (solar radiation) of the SPV system depends only on all these variables. The operational efficiency can also easily be modified for the other variables. Therefore, this analysis focuses on the elucidating temperature effect on various SPV parameters.

The effect on the overall performance of a photovoltaic system is examined by solar radiation, temperature, shadow, earth, and snow [60]. SPV cell output decreased gradually as the air temperature increased. However, changes in wind speed led to mixed reactions of the efficiency of the PV system [61].

The generation of electric and thermal energy is favored for green and sustainable methods, such as solar energy systems. These solar energy systems are an appealing choice for 


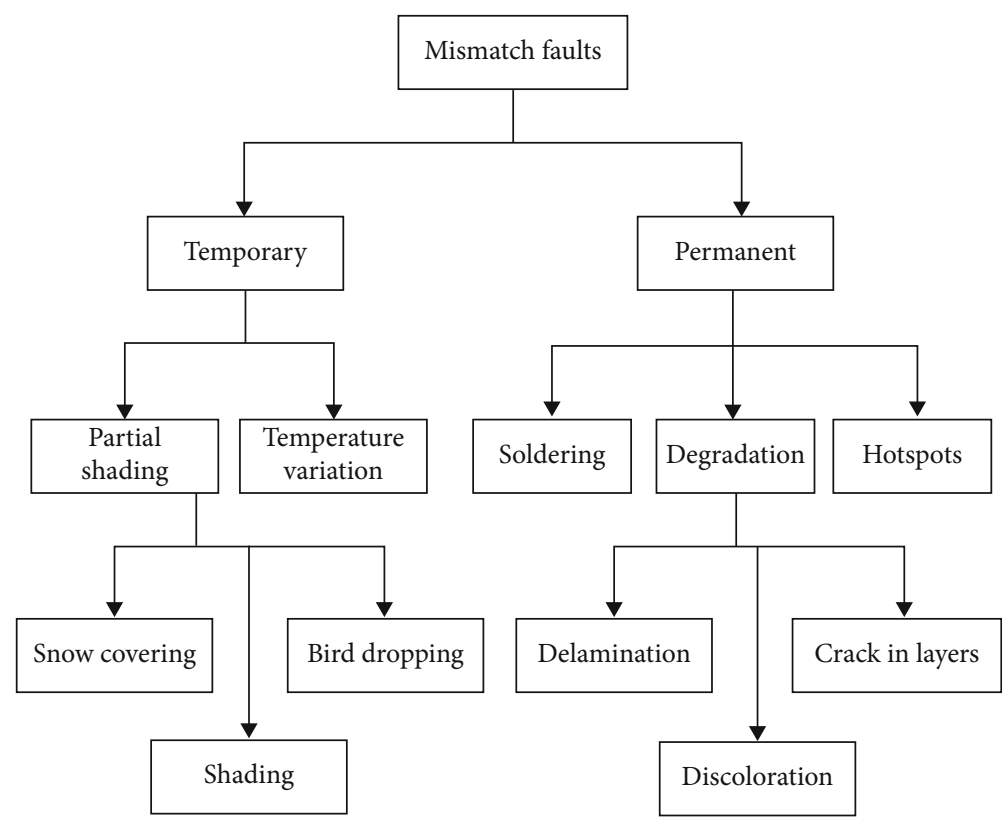

Figure 5: Classification of mismatch losses in solar photovoltaic module [171].

the electricity supply in remote areas and community use in particular. Other types of renewable energy sources (wind and biomass) are unsatisfactory for smaller development due to the high cost of supply and sustaining and operating life and by implementing solar-energy systems; these problems are overcome. However, the SPV systems have an extremely low power conversion performance due to the different types of losses during energy storage and transfer. Mismatch losses are a significant downside of such defeats. Mismatch losses affect the performance of SPV, which results in a hotspot event that decreases the working life of the SPV device and increases the cost of producing electricity.

The SPV method is the most common in space reduction; occurrences of solar radiation at a specific location are less common. Therefore, high energy conversion rates need efficient solar energy use and a suitable transformation process. Furthermore, the optimum power output can be achieved by minimizing power losses and reducing energy costs. Current research focuses on elucidating the inefficiency effect, enhancing performance, and developing SPV systems with optimized technologies.

Each solar power plant string consists of several photovoltaic modules. Each module's I-V characteristics vary because of the difference in internal resistance, shortcircuit current, and power modular loss. Strings of SPV power plants are located in parallel. The I-V features of the combined string and length of the outside cable are different [62].

2.5. Impact of Dust on SPV Modules. As the world's energy consumption increases and environmental concerns create, there has been an upsurge in interest in improving renewable power sources, particularly solar energy. Further electrical modeling research will focus on diode-based equivalent circuit models. It was discovered that dereliction of environ-

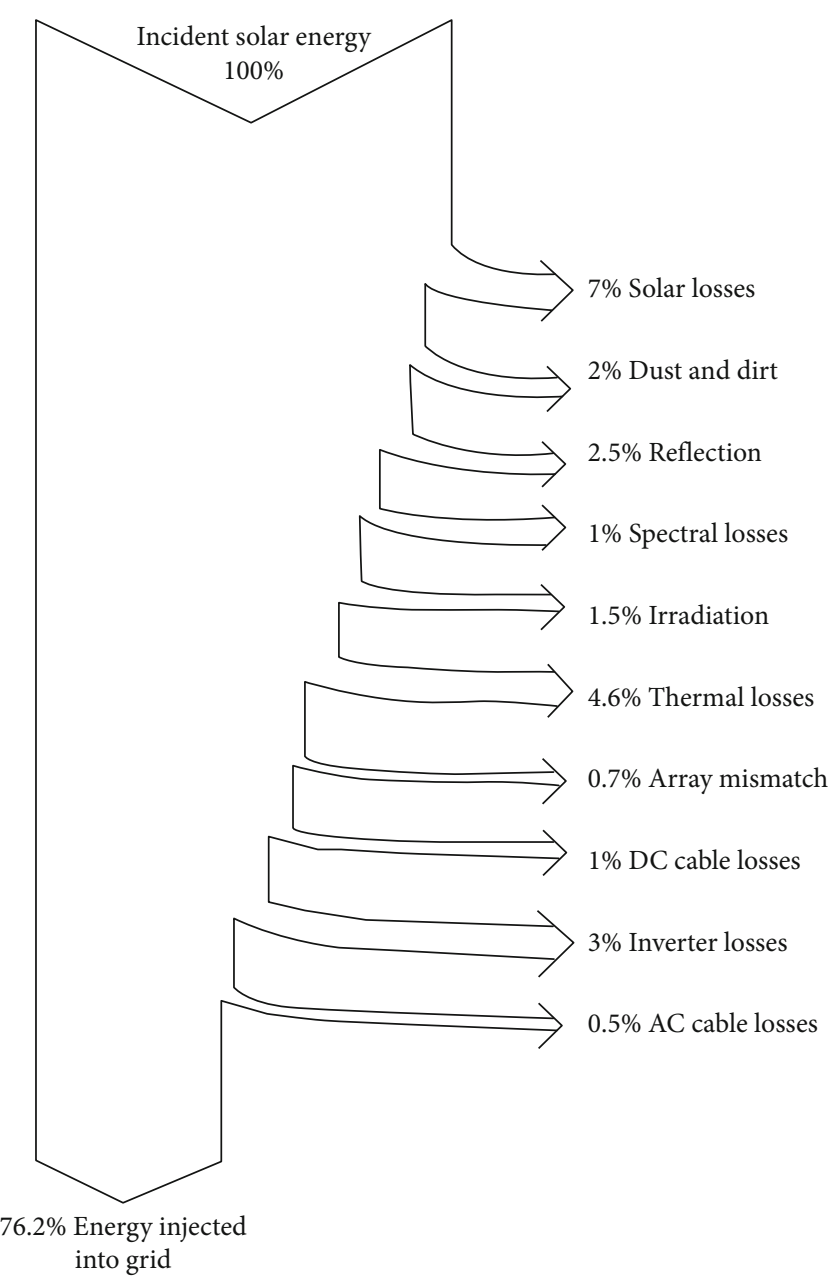

FIguRE 6: Sankey diagram for photovoltaic system losses [79]. 
TABLE 1: Mismatch losses in a solar photovoltaic cell/system.

\begin{tabular}{|c|c|c|}
\hline Connection scheme & Mismatch power loss & Authors \\
\hline $5 \times 5$ SPV array & $\begin{array}{l}\text { Maximum loss at total cross-tied of } 1214.93 \mathrm{~W} \text { and minimum loss at the dominant square } \\
\text { of } 606.75 \mathrm{~W}\end{array}$ & $\begin{array}{l}\text { Dhanalakshmi and } \\
\text { Rajasekhar[114] }\end{array}$ \\
\hline 40 modules & Mismatch loss is about $0.23 \%$ of the nominal power & Lorente et al. [115] \\
\hline $2.85 \mathrm{~kW}$ power plant & Annual electrical mismatch loss factor from $3.8 \%$ to $13.2 \%$ & Rodrigo et al. [116] \\
\hline $190 \mathrm{~kW}$ power plant & $\begin{array}{l}\text { Total loss including solar radiation, temperature, module quality, array mismatch, ohmic } \\
\text { wiring, and inverter is found to be } 31.7 \%\end{array}$ & $\begin{array}{l}\text { Sharma and Chandel } \\
\text { [117] }\end{array}$ \\
\hline $\begin{array}{l}\text { SPV cells connected } \\
\text { in a string }\end{array}$ & Fractional power loss due to mismatch is $2.35 \%$ & Bucciarelli Jr. [70] \\
\hline Series string & $15-20 \%$ & Wang and Xuan [118] \\
\hline
\end{tabular}

mental conditions could result in significant errors of up to $17 \%$. The accuracy of the predictions can be improved by up to $35 \%$ with simple model modifications like taking dust into account [63].

Red soil, ash, sand, calcium carbonate, and silica are examples of several types of pollution deposits. When SPV panels are exposed to the dust elements for short period (two months) without being cleaned of pollutants in the air, their energy yield can be reduced by as much as $6.5 \%$ $[64,65]$. Multicrystalline PV modules were tested in both indoor and outdoor environments for the influence of dust on their performance. Under varied contaminants, the PV module's performance has been evaluated. Due to the mass and kind of pollution, dust particles depositing on the PV module cause voltage and output power to decline [66].

There were detrimental effects on output power and short-circuit current when dust was collected on the polycrystalline silicon photovoltaic module. However, the opencircuit voltage was not significantly influenced by this phenomenon. Coal dust was shown to have the greatest impact on module efficiency, with a $64 \%$ reduction, followed by $42 \%, 30 \%$, and $29 \%$ for aggregate, gypsum, and organic fertilizer dust, respectively [67]. PV modules can be partially or completely shaded by dust accumulation on them. As a result, shading effects are not the same as those caused by dust or dust soiling. In PV modules with dust-soiled solar cells, the power output of the cells is lowered because less or no current is created [68].

2.6. Mismatch Effects. Depending on the system configuration and string length, the manufacturing assessment found changes between $0.01 \%$ and $3 \%$. Besides the module's electrical characteristics, a loss difference includes string length and edge effects [69]. When modules are connected to serial and parallel combination networks known as arrays, varying current-voltage characteristics of the photovoltaic modules result in a form of power loss called an electric mismatch. The "mismatch loss" (MML) effect is that the SPV-array total power output is less than the total module power output as if it was operating independently $[3,70]$.

A comprehensive performance model at the cell level is used to classify the actual array and $P_{\text {Array }}$ efficiency, which includes losses in discrepancy, as shown in Figure 4. This is compared to the ideal performance of ubiquitous $\sum P_{\text {Cells, }}$, the amount of individual cell-level power minus losses of

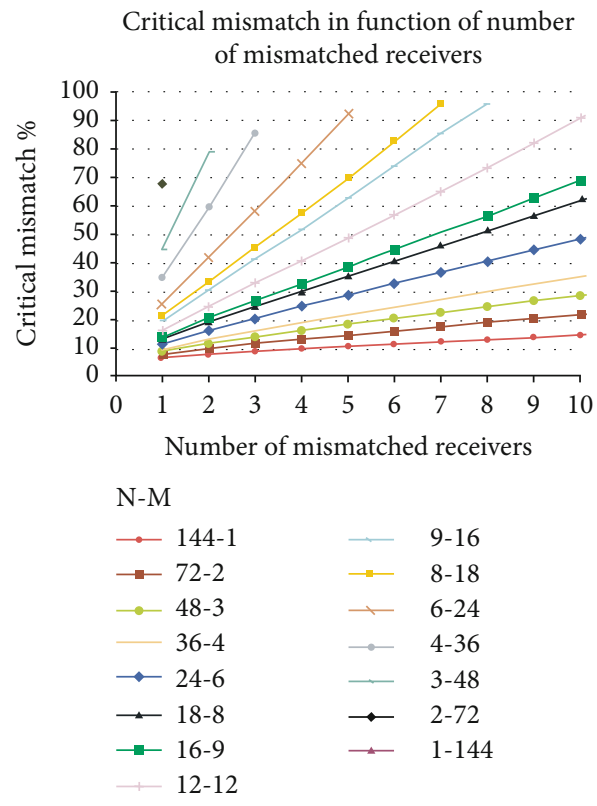

Figure 7: Critical mismatch values in function to the number of mismatched receivers for different electrical module layout configurations [172].

mismatch. Mismatch loss is therefore calculated by [71]

$$
\text { Mismatch loss } \%=\text { MML[\%] }=1-\frac{P_{\text {Array }}}{\sum P_{\text {Cells }}} \text {. }
$$

The actual flow through each module must be the same as that when the modules are connected to a string serial and connected to an inverter with a maximum power point for the tracker. The current passing through any module should be the same when the modules are connected to a series string and connected to an inverter with full shadow capacity [72].

The losses in SPV system loss due to the temperature are as follows:

(1) Loss due to the incident solar radiation level

(2) Loss due to the temperature

(3) Loss due to the SPV module quality 


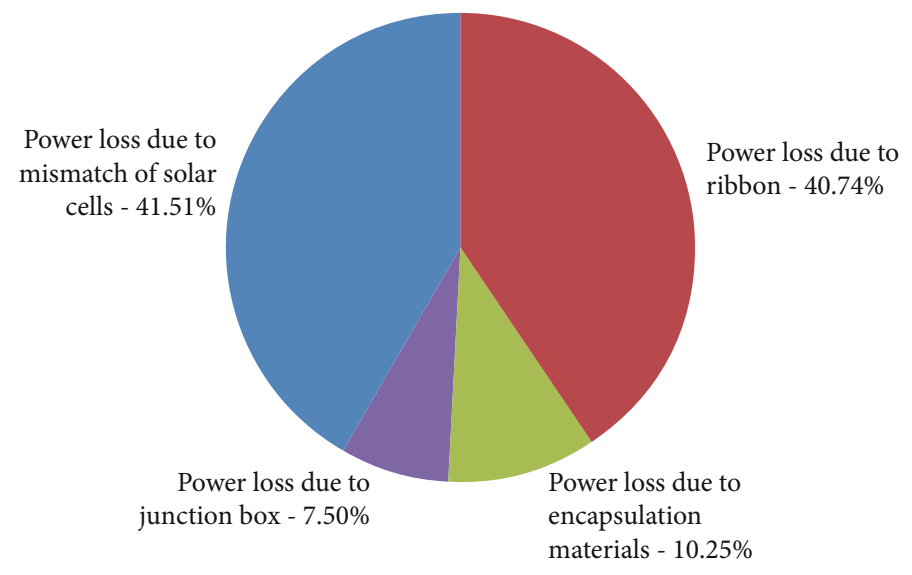

FIGURE 8: Distribution of power loss in a solar module [173].

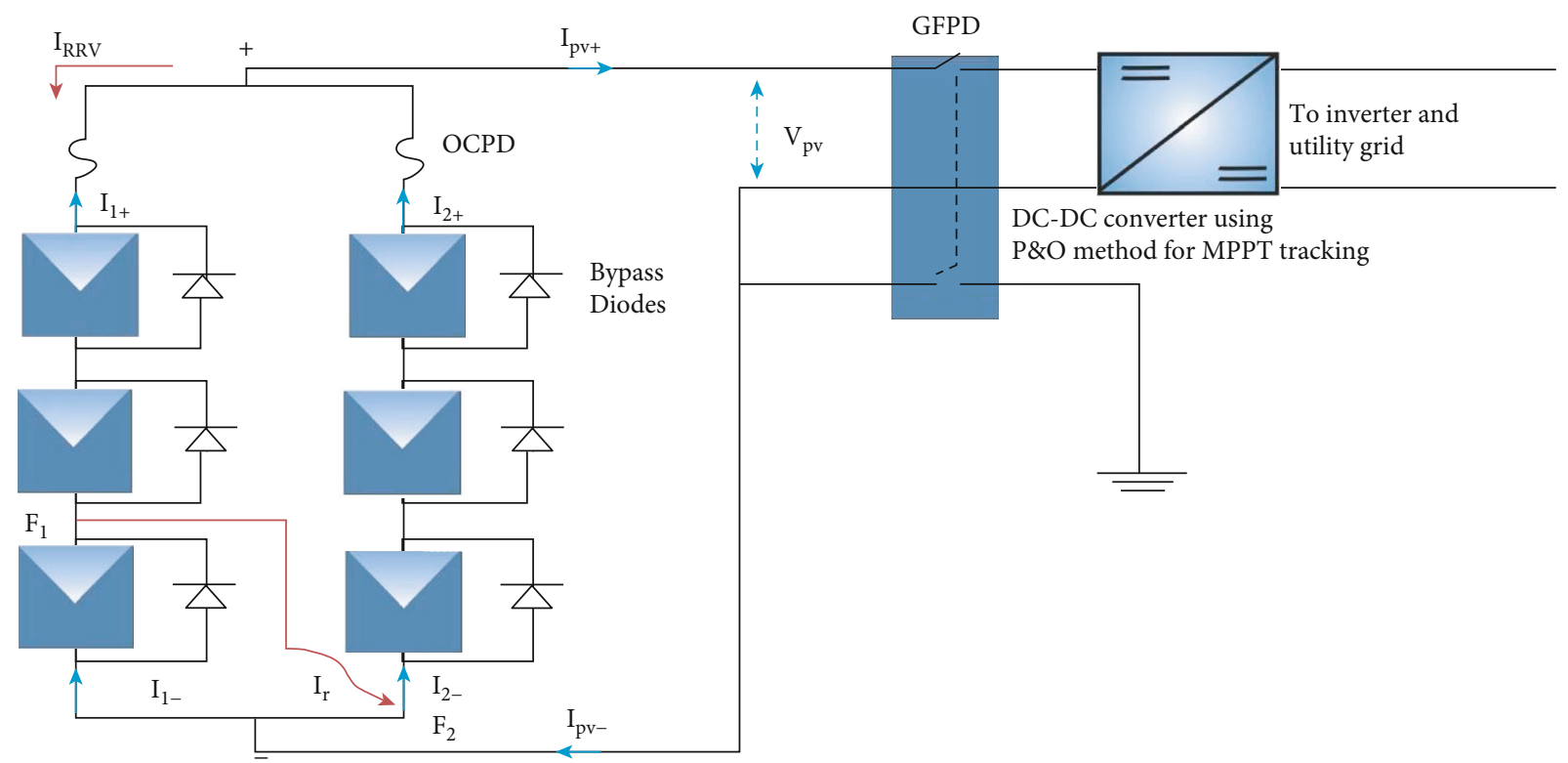

(a)

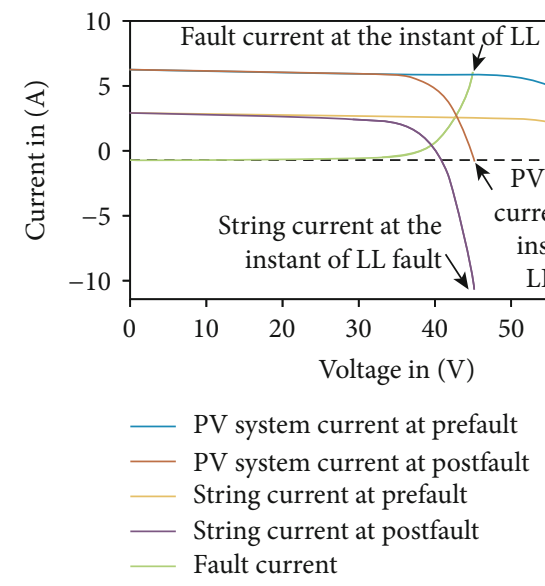

(b)

FIGURE 9: (a) SPV system without blocking diodes in the event of a fault. (b) I-V without blocking diodes [82]. 


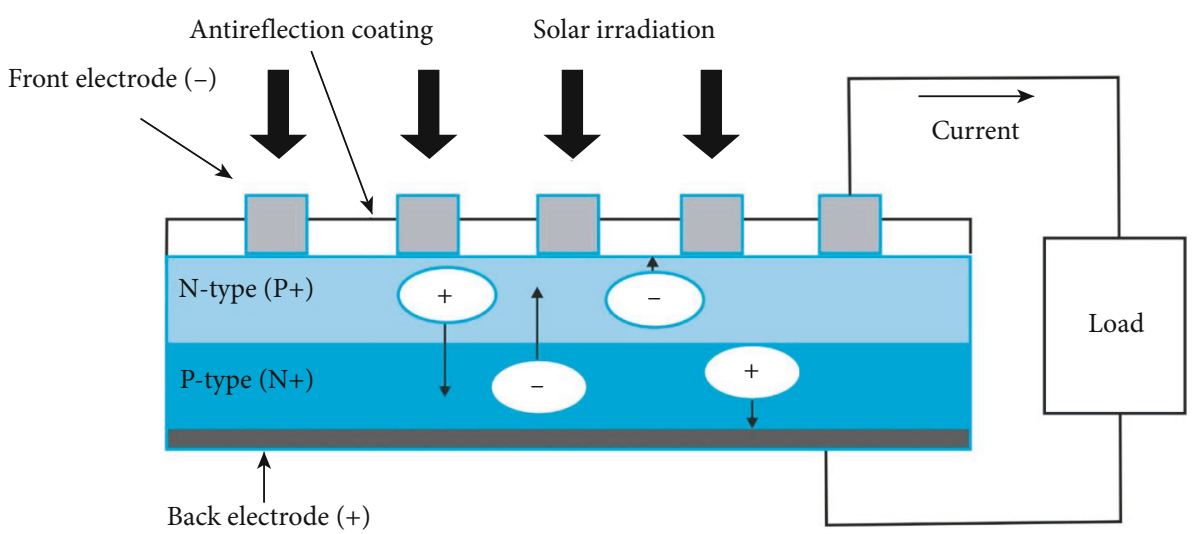

Figure 10: A p-n junction SPV cell structure [83].
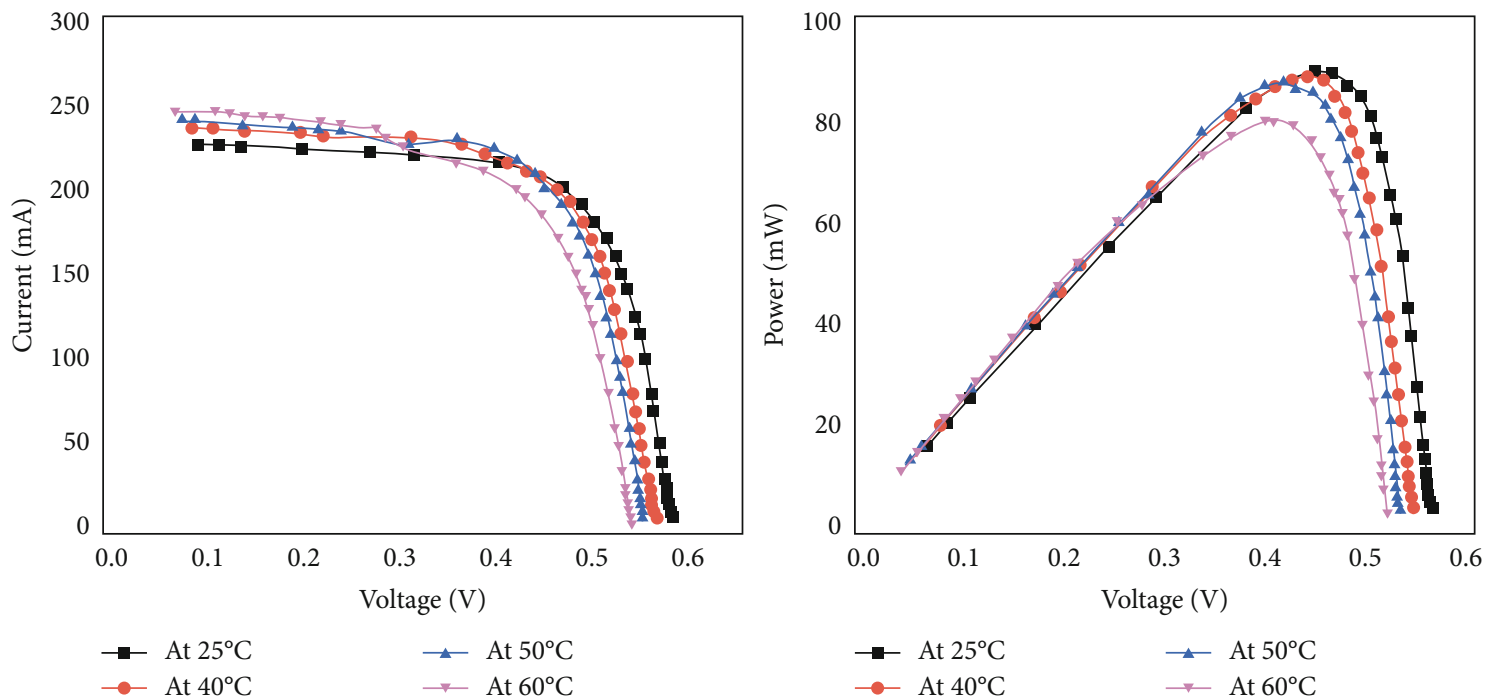

Figure 11: An m-Si SPV cell's current-voltage and power-voltage characteristics are displayed at solar radiation of $515 \mathrm{~W} / \mathrm{m}^{2}$ [84].

(4) Loss due to mismatch phenomenon between strings

(5) Ohmic loss due to wiring

(6) Loss at the inverter level due to its efficiency and its operation

In addition, it is crucial to match the maximum power output of the SPV modules to the accurate DC-AC inverter size to avoid unaccounted losses [73].

2.7. Mismatch Loss in Solar Photovoltaic Modules. Figure 5 demonstrates the description of the SPV module defects. It has briefly and permanently broken up into incompatibility losses. Temporary partial shade loss, temperature variations, covering snow, and falling birds are barriers to maximum solar light absorption by prominent photovoltaic components. The effect of defects in the photovoltaic module is equally soiling defects, corrosion, lightning, delaminating, cracking of the coating, and coloration.
The Sankey diagram indicates some losses in photovoltaic systems shown in Figure 6. Due to the low energy efficiency of SPV systems, the energy produced should be with minimum losses, be moved to consumers as much as possible. Through the elimination of loss factors in the photovoltaic systems, these losses must be minimized.

Factors that may cause SPV system losses include environmental factors such as wind, dust, snow, heat, temperature, and other losses caused by device components such as cables, inverters, and batteries. Given the losses, the SPV system should be installed and used to the greatest extent possible for the energy generated in local regions.

Photovoltaic plates are caused by the deposition of soil and dust. The powder is used in any event to wash rainfall off the module's surface, and even bird waste remains on the panel's surface after heavy precipitation. One of the main parts of the SPV unit is the lower edge of the module. The module is usually mounted on the ground with slight inclines such that the water between the container edges is 


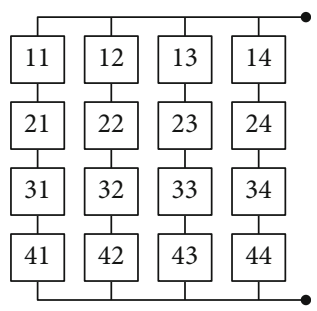

(a) SP

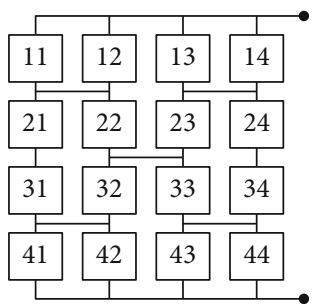

(c) $\mathrm{HC}$

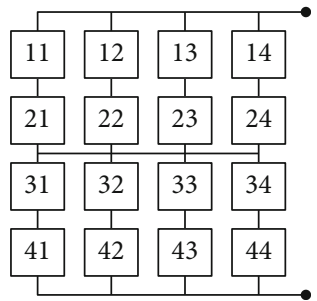

(e) SP-TCT

\begin{tabular}{|c|c|c|c|}
\hline 11 & 12 & $\frac{1}{13}$ & 14 \\
\hline & & & \\
\hline 21 & 22 & 23 & 24 \\
\hline 31 & 32 & 33 & 3 \\
\hline & $\theta$ & & $=$ \\
\hline 41 & 42 & 43 & 44 \\
\hline
\end{tabular}

(g) BL-TCT

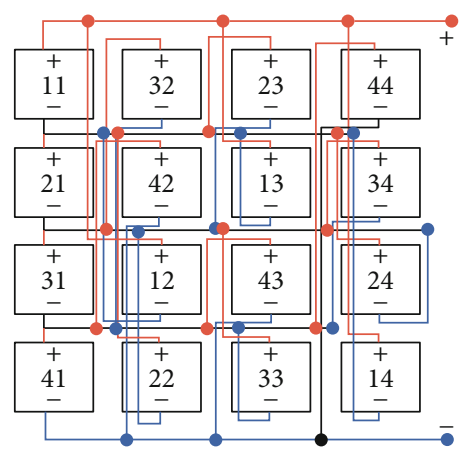

(i) $\mathrm{SDK}$

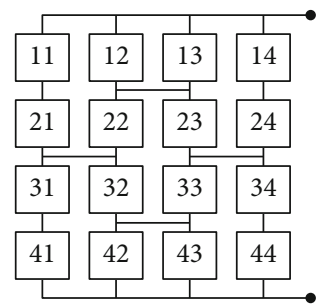

(b) $\mathrm{BL}$

\begin{tabular}{|c|c|c|c|}
\hline 11 & 12 & 13 & \begin{tabular}{|l|l}
14 \\
\end{tabular} \\
\hline & 早 & 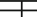 & 4 \\
\hline 21 & 22 & 23 & 24 \\
\hline 31 & 32 & 33 & 34 \\
\hline 41 & 42 & 43 & \\
\hline & & & \\
\hline
\end{tabular}

(d) TCT

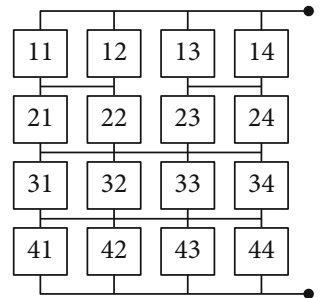

(f) BL-HC
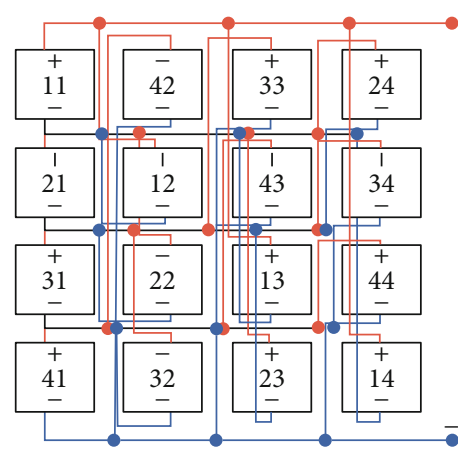

(h) LS-TCT

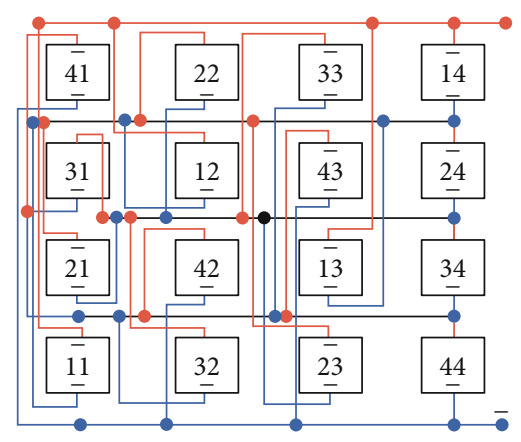

(j) SPDK

Figure 12: Continued. 


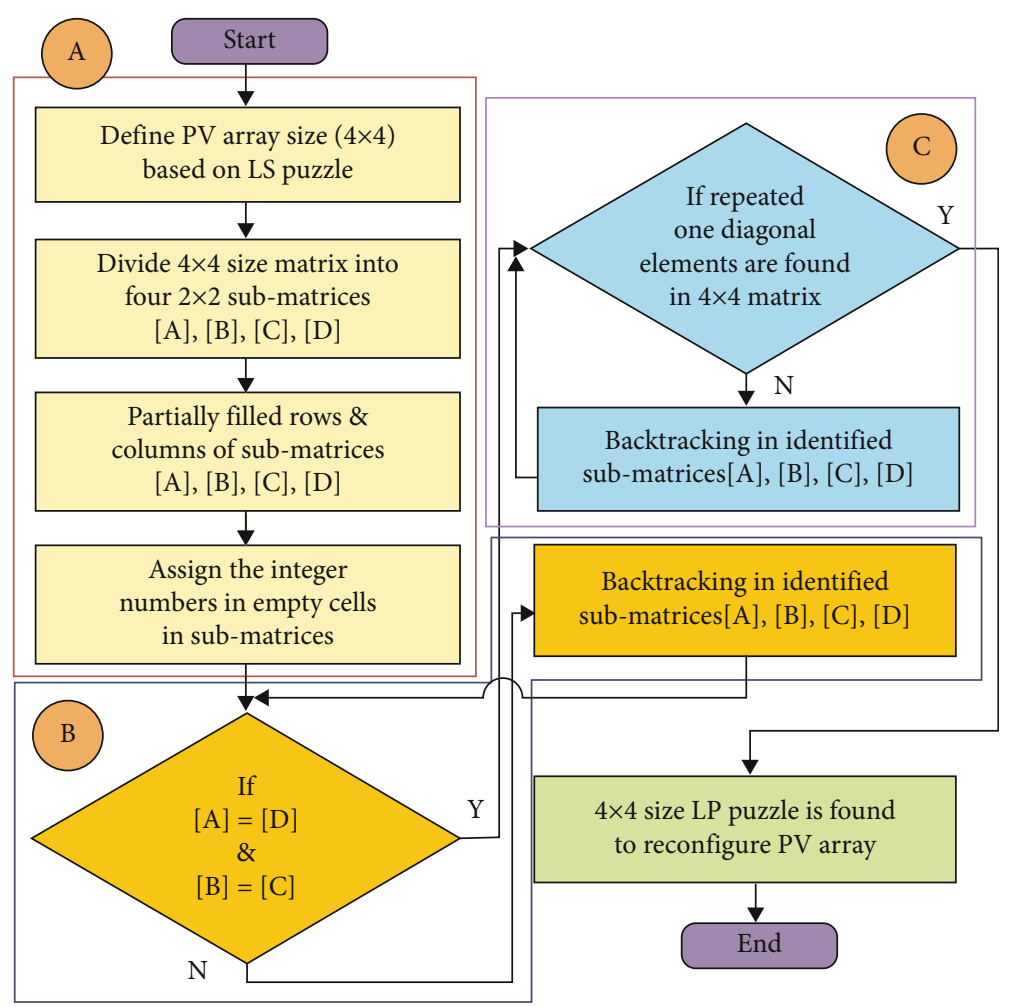

(k) Flow chart for LS methodology to design $4 \times 4$ size of PV array

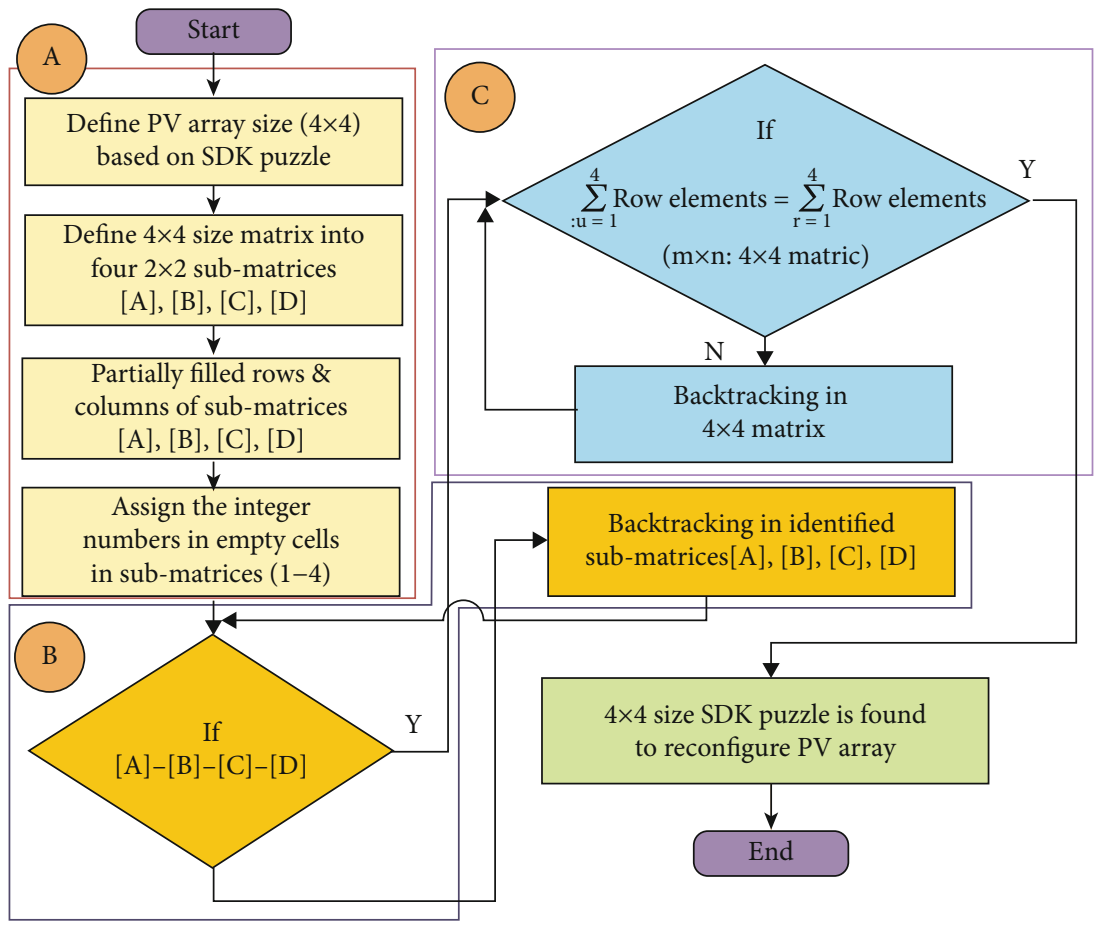

(1) Flow chart for SDK methodology to design $4 \times 4$ size of PV array

Figure 12: Continued. 


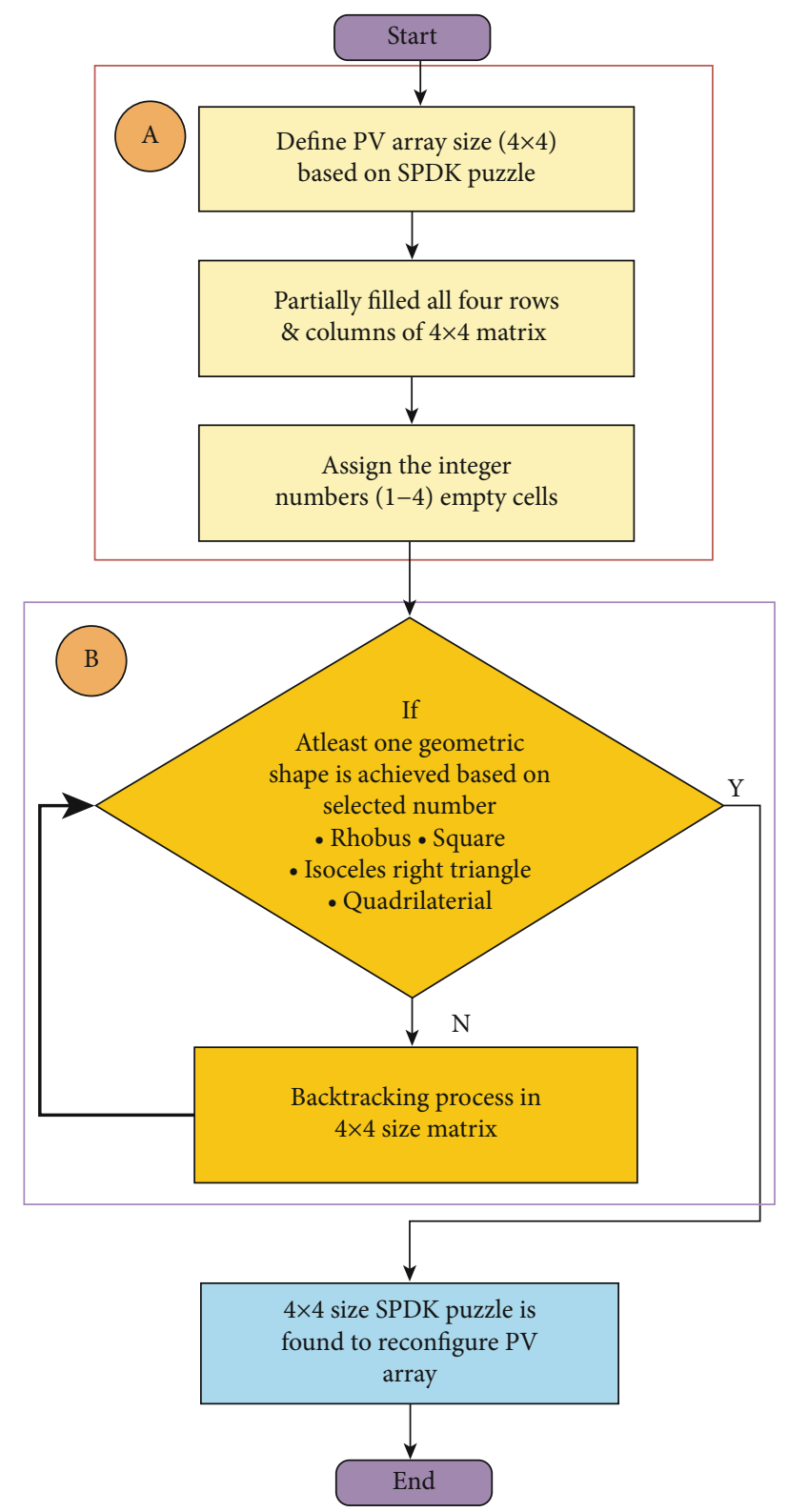

(m) Flow chart for SPDK methodology to design $4 \times 4$ size of PV array

Figure 12: $(\mathrm{a}-\mathrm{m})$ Configurations and flow charts for conventional, hybrid, game puzzle-based SPV arrays [85-89].

constantly not collected at the ends of the kit. The dust reduces a module's maximum power by shielding the cells from the soil. Loss should be less than 1 to $2 \%$ to return to power when the modules are periodically cleaned and to eliminate soil losses from the modules only through frequent cleaning cycles $[74,75]$.

Photovoltaic panel surfaces should be kept clean at ground level for good system performance during service so that solar radiation can be absorbed more effectively. A smart machine can be used in some studies to clean the floor, whether manually or automatically. The design is aimed at reducing productivity losses by dust and dirt on the surface of the panel and at maximizing power production. The energy loss without the purification cycle has been reduced and efficiency increased by $15-20 \%$ [76]. Mismatch loss occurs in various capacity ranges of power plants given in Table 1.

A case study with 180 solar panels from Panasonic N285 and multiple SMA inverter topologies has been presented in a $51 \mathrm{~kW} \mathrm{SPV} \mathrm{array} \mathrm{on} \mathrm{the} \mathrm{roof.} \mathrm{Listing} \mathrm{has} \mathrm{been} \mathrm{measured}$ for low, medium, and shaded scenarios. Six configurations of SPV strings have been analyzed ((1) system with $10 \times 5$ $\mathrm{kW},(2) 5 \times 10 \mathrm{~kW},(3) 5 \times 10 \mathrm{~kW}$, (4) $3 \times 15 \mathrm{~kW}$, (5) $2 \times 25$ $\mathrm{kW}$, and (6) $1 \times 51 \mathrm{~kW})$. The control demonstrated the varying output in all configurations when shading scenarios were considered, resulting in maximum power available in shadow conditions. Shade losses of $21.4 \%, 22.9 \%, 26 \%$, $24.2 \%$, and $23 \%$ have been observed during testing with the free online simulation $\mathrm{PV} * \mathrm{SOL}$ software for all six configurations [77]. 
TABLE 2: Studies on the effect of solar radiation.

Objectives
Examine the solar photovoltaic panel's surface temperature about
solar radiation and ambient temperature.

solar radiation and ambient temperature.

The SPV performance characteristics were calculated using measurements of the panel's output voltage and current, as well as the amount of solar radiation incident on its surface and the panel's surface temperature.

According to the location and time of day, the amount of solar radiation that falls on SPV panels might vary significantly.

When the atmosphere is partly cloudy, the differences in solar radiation can produce considerable oscillations in system currents, notably in battery currents.

An investigation into the relationship between solar radiation, current, voltage, and solar panel efficiency is the fundamental objective of this research effort.

Solar radiation transfer may be predicted using a new, more comprehensive physical model that incorporates deposition and particle characteristics.

The solar photovoltaic panels are most efficient when the solar radiation hits them head-on in a direct line. An SPV panel that is stationary can only face the sun for a limited amount of time.

Different solar radiation intensities ranging in the range of 1000 $3000 \mathrm{~W} / \mathrm{m}^{2}$ have been examined to determine the power and energy of SPV cells.

Aspects such as the amount of solar radiation reaching the panels, the surrounding temperature and humidity, and the wind speed are all readily apparent. The amount of dust or pollution that accumulates on solar panels depends on the local climate and precipitation, which affects the amount of electricity generated.
Result

References

At an ambient temperature of $36^{\circ} \mathrm{C}$, the solar panel reached a temperature of $78.50^{\circ} \mathrm{C}$ when exposed to $1140 \mathrm{~W} / \mathrm{m}^{2}$ of solar radiation. The performance of SPV panels can be harmed by extended exposure to high panel temperatures, even at typical levels of solar radiation and ambient temperature.

Humidity causes a decrease in solar radiation and panel output, according to the studies. The SPV panel's power output drops by $34.22 \%$ when humidity rises by $50.15 \%$. It was also discovered that an $11.40 \%$ drop in panel temperature was caused by a rise in humidity from $65.40 \%$ to $98.20 \%$.

A small increase in SPV panel voltage is observed when panel current rises in direct proportion to solar radiation. Similarly, the power of a solar panel increases as a function of the amount of solar radiation it receives.

Cycled battery charge/discharge currents are directly affected by changes in solar radiation. Battery current changes caused by solar radiation cannot be modeled using hourly radiation data.

Tripathi et al.

The temperature rises as a direct result of increased solar radiation, according to the results obtained from the experiment. The output current rises as a result of the increase in solar radiation until the cell's temperature interferes and causes it to fall.

There must be a consideration for all of these factors when forecasting the transmittance of a solar panel covered with dust, according to their studies.

The efficiency of the SPV system was shown to increase significantly when the SPV system was used with a sun tracking system. Depending on the panel's location, it can gain anywhere from $15 \%$ to $45 \%$ of its original energy throughout the year.

Increasing solar radiation from 1000 to $3000 \mathrm{~W} / \mathrm{m}^{2}$ increases total energy by approximately $1797.56 \%$.

The wind helps to keep the SPV panel cool by reducing the amount of electricity lost as a result of increased solar radiation or elevated panel back temperature.
Tripathi et al.

Karafil et al. [121]

McCormick and Suehrcke

Buni et al.

Xingcai and Kun [124]

Thorat et al. [125]

Nasrin et al. [126]

Kazem and

Chaichan

[127]
The contrast was made with the genetic algorithm performance and other conventional techniques using $400 \mathrm{~W}$, $3400 \mathrm{~W}$, and $9880 \mathrm{~W}$ arrays, each consisting of $40 \mathrm{~W}, 10 \mathrm{~W}$, $85 \mathrm{~W}$, and $247 \mathrm{~W}$ SPV modules. The respective array output power and MML are calculated for both the long series string- (LSS-) SP and long parallel branch- (LPB-) SP arrays. For this function, array arrangements $1 \times 40,2 \times 20,4 \times 10$, and $5 \times 8$ (parallel $\times$ series) are used as LSS-SP array while array arrangements $40 \times 1,20 \times 2,10 \times 4$, and $8 \times 5$ are known as LPB-SP array configuration [78].

The basic inconsistency of the number of inconsistent recipients is shown in Figure 7, for different configurations. The SPV module design with a greater number of interconnected cell series has a lower critical differential value that allows the system to recover better. The nonuniform malfunction distribution has been checked for an erroneous modulus structure analysis $(16 \times 9)$. This means that each receptor gets the inconsistency value by increasing the number of inconsistent cells until the inconsistency of all receptor cells is reached [79]. The relative malfunctions were between 1.4 and $4.0 \%$ during the stated solar radiation transfers according to the electric configuration and layout of the SPV array [80].

Figure 8 demonstrates the energy loss distribution of the crystalline silicon solar cell. The electricity loss caused by discord between solar cells and ribbons is $41.51 \%$ and $40.74 \%$. The losses in the power of container materials and the link box are $7.5 \%$ and $10.25 \%$. The gross Cells to Module 
(CTM) of the solar panel of $72(25 \mathrm{~mm} / 125 \mathrm{~mm})$ is $3.93 \%$ [75]. The effect of the shunt on the power output of the module was tested in terms of relative power and relative open-circuit voltage. The important finding is that in so much as $90 \%$ variation between shunt positions in relative energy losses and the difference in relatively open circuit voltage losses can also be achieved, which is crucial that the electrical output of the SPV module shunted into the module depends on the mutual location and proximity of metallization. In comparison with metallization shunts, the relative strength of most shunts not for the lowest shunt resistance values has increased by $80 \%$ to $90 \%$ [81].

2.8. Circuit Implementation. It is common for SPV systems to have problems at various points, including the SPV arrays and power converters. As shown in Figure 9(a), the SPV array errors, such as line to line (L-L) faults, occur between the system's first and second strings. For the SPV system without blocking diodes, the string current at prefault and postfault conditions as well as the fault current $\left(I_{\mathrm{F}}\right)$ is shown in Figure 9(b). The L-L faults reverse the flow of current through faulty strings, as shown in Figures 9(a) and 9(b). $F_{1}$ and $F_{2}$ are separated by one healthy string, which generates an inward or reverse current $\left(I_{\mathrm{REV}}\right)$ into the faulty string. For SPV systems, the Overcurrent Protection Devices (OCPDs) used in SPV systems can easily detect a shortcircuit current that is almost twice as high as that of the string before the fault, as shown by Figure 9(b) [82].

Different semiconductor materials are used to build the solar cell's two layers, each of which is doped differently. Figure 10 illustrates the basic structure of a silicon solar cell. A p-n junction diode is a better analogy for the solar cell. A layer of silicon with integrated metal components is utilized on the upper side of the electrode to prevent direct solar radiation penetration. As a result of connection resistance, SPV cells can be built in a variety of forms to maximize their effective surface area and minimize their losses due to this resistance [83].

Figure 11 depicts the m-Si SPV cell's current-voltage and power-voltage curves at constant solar radiation. Photovoltaic cell temperatures of $25^{\circ} \mathrm{C}, 40^{\circ} \mathrm{C}, 50^{\circ} \mathrm{C}$, and $60^{\circ} \mathrm{C}$ were observed at solar radiation of $515 \mathrm{~W} / \mathrm{m}^{2}$. A direct correlation between cell temperature and current-voltage characteristics can be shown in Figure 11. It has been found that at lower voltages, the current is the largest and most nearly constant, with constant solar radiation of $515 \mathrm{~W} / \mathrm{m}^{2}$ and $220-240 \mathrm{~mA}$ [84].

\subsection{Configurations for SPV Arrays}

\section{(1) Customized SPV array constructions}

There are numerous SPV array configurations depicted in Figures 12(a)-12(h). In addition to the SP and BL-based combinations, there are SP-TCT and BL-HC hybrids, as well as the projected LS-TCT variants. Figures 12(a)-12(c) depict the standard SP, BL, and $\mathrm{HC}$ configurations for a 44-panel SPV array. It is shown in Figure 12(d) that an SPV panel array of 44 panels can be generated with high power by employing tied across individual rows of interconnections.

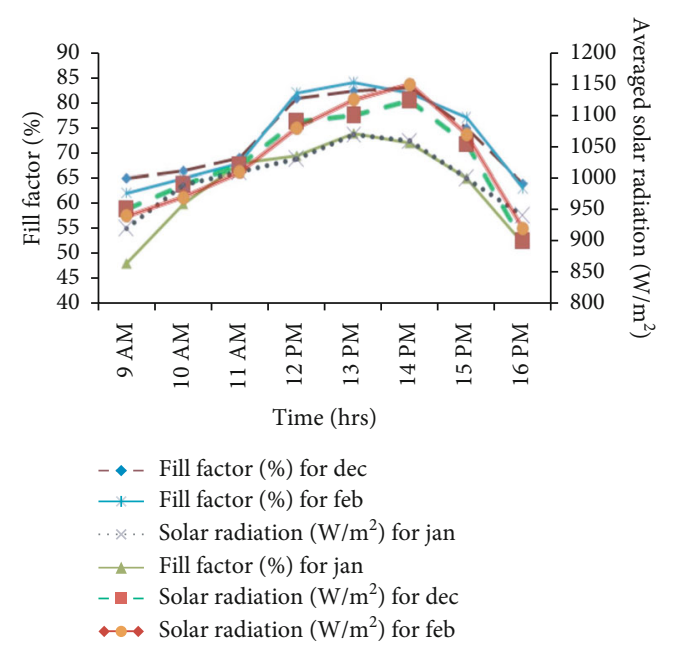

FIGURe 13: Performance characteristics curve for SPV system with the effect of solar radiation [174].

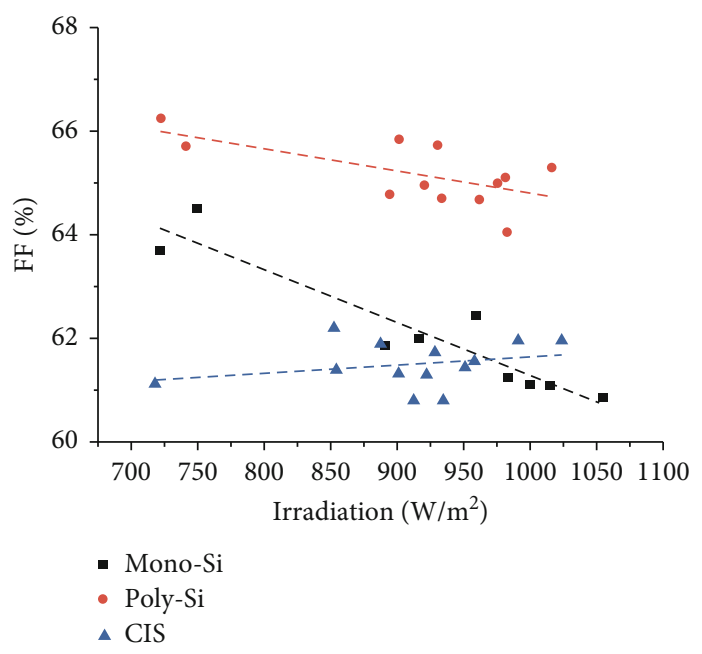

FIgURE 14: Effect of solar radiation on mono-Si, poly-Si, and CIS materials [132].

Combining the traditional SP, BL, and $\mathrm{HC}$ topologies with the TCT topology of an SPV array is shown in Figures 12(e)-12(g) [85].

\section{(2) ls puzzle-based SPV array configuration}

Figure 12(h) shows a puzzle pattern-based SPV array topology in which the positions of SPV modules are reallocated according to a modified TCT, but electrical interconnections remain the same. The SPV modules in this array are identified by the first and second numbers of their row and column names, respectively. The purpose of LS is to identify the maximum number of rows and columns that can be employed for an integer. Leonard Euler devised a matrix in which each symbol appears exactly once in every row and column. Perceptible shading dispersion during SPV array reconfiguration is available in the presence of partial shading conditions (PSCs). The shade dispersion property will always change based on the number of integers 
TABLE 3: Studies on the effect of temperature.

Objectives
The temperature of SPV panels under realistic settings is being
modeled theoretically.
modeled theoretically.

Photovoltaic conversion is mainly influenced by the operating temperature. Temperature affects both the module's electrical efficiency and its output power linearly.

Analyzing the behavior of a monocrystalline SPV panel under various temperatures is done using MATLAB/Simulink software.

Real-time solar radiation and ambient temperature will be used to evaluate the influence of heating on SPV cells' efficiency.

Temperature and solar radiation affect the performance of $\mathrm{m}-\mathrm{Si}$ silicon, p-Si, and Copper Indium Diselenide (CIS) modules under real-environmental conditions.

The temperature coefficients of commercially available solar modules are examined.

Filtering certain spectrum solar radiation before entering an SPV panel might result in various temperature profiles and varying output powers.

A p-Si photovoltaic panel is tested for its electrical performance under various temperature conditions.

An investigation into the performance of a specific type of solar panel. Since it has an open design and can therefore benefit from natural ventilation, it is self-cooling and keeps dust from collecting on its surface even during the hottest parts of the day.
To accurately measure the heating effect, the temperature coefficient of the solar cells is utilized. A decrease in photoelectric efficiency of $2.9-9.0 \%$ occurs in solar cells having a temperature coefficient of 2.1$5.0 \%$.

The photovoltaic conversion process is heavily reliant on controlling the operating temperature. An SPV module's electrical efficiency and, by extension, its output power are directly proportional to its operating temperature, which decreases linearly with module temperature.

Photovoltaic system efficiency is greatly affected by the temperature of the solar cells.

Achieving maximal performance and maximum output from a solar energy harvesting module requires that its temperature be kept within an acceptable range for the SPV module.

Temperature affects the efficiency and fill factor of $\mathrm{m}-\mathrm{Si}$ and $\mathrm{p}$-Si modules; this is not the case with CIS modules.

CdTe-based modules have an average temperature coefficient of power of $-0.446 \% /{ }^{\circ} \mathrm{C}$ for $\mathrm{m}-\mathrm{Si}, 0.387 \% /{ }^{\circ} \mathrm{C}$ for $\mathrm{p}-\mathrm{Si}$, and $0.172 \% /{ }^{\circ} \mathrm{C}$ for CdTe-based modules correspondingly.

The temperature profile of an SPV panel is altered when solar energy is filtered before it enters the panel, resulting in lower panel temperatures in all cases (on average $18 \%$ reduction).

An increase in temperature reduces panel efficiency by $0.5 \% / \mathrm{K}$, in total. In addition, a drop in SPV module efficiency of $1.23 \%$ was caused by a rise in temperature of $30^{\circ} \mathrm{C}$.

With the help of this Computational Fluid Dynamics

(CFD) model, it was demonstrated that a lower temperature in this solar system allows for maximum electrical production than a flat SPV system.

References

Du et al.

Dubey et al.

Zaini et al.

Thong et al.

Perraki and

Kounavis

[132]

Dash and

Gupta [133]

Schoeman

et al. [134]

Idzkowski

et al. [135]

Charfi et al. [136]

utilized in the puzzle design. Because of this, it is feasible to place LS puzzles with distinct attributes and multiple placement choices for integer numbers. An SPV array has been reconfigured with the help of the LS puzzle, as shown in Figure 12(k) [86].

\section{(1) Su-do-Ku puzzle-based SPV array configurations}

The four-by-four SPV array is rearranged by a series of rules based on integer numbers. Electrical connections and design methods are illustrated in Figure 12(i).

(2) Shape-do-Ku puzzle-based SPV array configuration

It is possible to find the Shape-do-Ku (SPDK) puzzle in a variety of sizes, although it has no technological connection to the Su-do-Ku (SDK) puzzle. This puzzle has only one possible answer, and each number must occur at least once in every row and column. Rearranging the SPV array with a 4

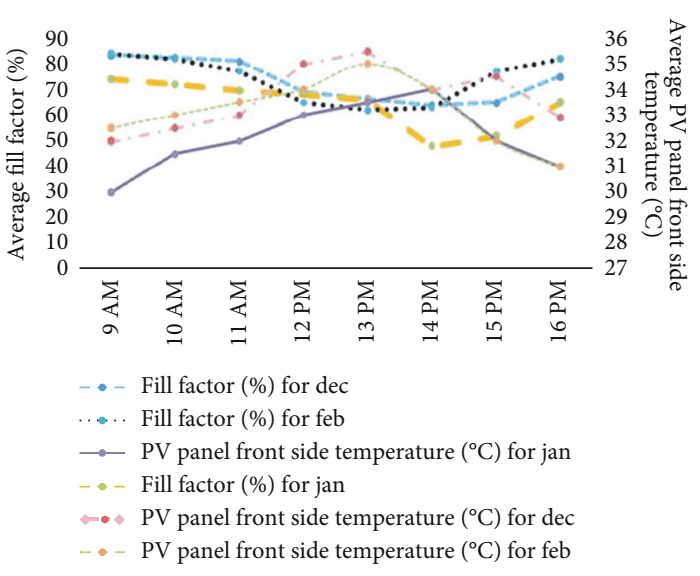

FIgURE 15: Performance characteristics curve for SPV system with the effect of SPV panel front side temperature [174]. 
TABLE 4: Studies on the effect of relative humidity.

Objectives
Relative humidity affects the effectiveness of solar panels in Calabar,
Nigeria, while converting solar energy to electricity.
Solar modules' primary characteristics, voltage, current, power, and
efficiency are all studied parametrically for their effects on each
other.
The effects of temperature and relative humidity on the operation of
photovoltaics put near the Calabar River were investigated to
evaluate their efficiency.

The deposition of the Hole Extraction Layer (HEL) does not appear to be affected by humidity or oxygen; however, the deposition of the perovskite layer is notoriously affected by humidity and oxygen.

Electrical energy production, the efficiency of SPV conversion, and efficiency losses were all examined about weather data. The results show that output is lower during periods of high relative air moisture.

According to research, solar cell performance is affected by weather conditions such as relative humidity and temperature.

Under variable humidity and precipitation circumstances, a more generalized mathematical model for dust deposition has been proposed.

It was found that a two-phase, standing-wave electrodynamic dust shield (EDS) was more successful in removing dust in a single operation mode with constant $\mathrm{RH}$ and a cyclic operation mode with alternating $\mathrm{RH}$ conditions.

Solar radiation models are adjusted based on the relative humidity and the air quality index (AQI) of a given area.

It has also been discovered that the voltage is relatively

stable between 70 and $74 \%$. Low relative humidity

(between $70 \%$ and $74 \%$ ) increases this efficiency even further.

For p-Si modules, generated power and efficiency are more affected by relative humidity variation than the voltage in the range of $10 \%$ to $50 \%$.

References

Ettah et al. [137]

Relative humidity has been found to have a negative correlation with current, efficiency, and photovoltaic system performance.

Sohani et al.

Njok and

Ogbulezie

[139]

The triple-cation perovskite layer was used to prepare the best-performing device and was deposited under dry air, resulting in an efficiency of $16.7 \%$ for power conversion.

Mesquita

et al. [140]

Solar panel designers, installers, and end-users of SPV systems can benefit from the findings for improved system design and more accurate energy production forecasts.

Burduhos

et al. [141]

There was a significant drop in the efficiency of solar cells when working in conditions like high

temperatures and relative humidity of more than $70 \%$.

Hamdi et al.

As humidity levels rise, the deposition rate of a particle increases, and its rebound rate decreases. With an increase in relative humidity of 40 to $80 \%$, the rebound velocity of a $2.5 \mu \mathrm{m}$ particle decreases by $73 \%$ from 0.073 to $0.019 \mathrm{~m} / \mathrm{s}$.

EDS devices can now be designed and operated optimally, including determining the ideal timing of EDS activation and applying appropriate dielectric coverings and hydrophobic coatings to the EDS' top surface.

Relative humidity and AQI were exposed to be the most effective adjustment methods. The accuracy and reliability of solar radiation models that deteriorate layer by layer can be improved using this technique.

Su et al.

[145]

Javed and

Guo [144]

Sengupta

et al. [143]

$\times 4$ SPDK puzzle is done. There is a diagram of electrical connections and design methods in Figures 12(j) and $12(\mathrm{~m})$ [87-90].

\section{Causes of Mismatch Losses}

Environmental and operational variables have a separate effect on the SPV panel into three groups (solar radiation effect, temperature effect, and relative humidity effect). Input parameters for solar radiation SPV systems are environmental factors that determine the SPV system performance, temperature, and relative humidity.

3.1. Effect of Solar Radiation. Table 2 summarizes research on the impact of solar radiation on solar photovoltaic panels conducted by various researchers. The overall effect of SPV cells has increased the fill factor by increasing solar radiation, as shown in Figure 13. The average fill factor for the SPV module varied between initial and final values of about $22.98 \%, 54.16 \%$, and $26.19 \%$, with $18.18 \%$ and $14.01 \%$, and

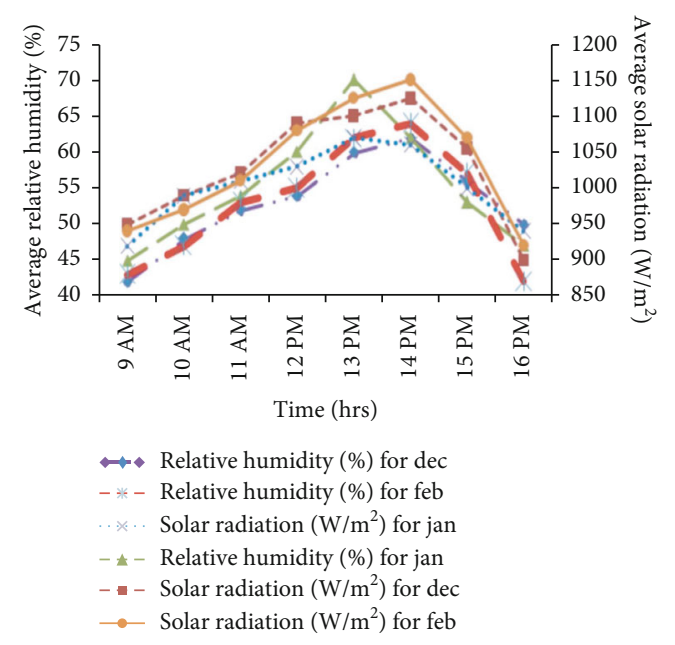

FIgURE 16: Performance characteristics curve on SPV module with the effect of relative humidity [174]. 
TABLE 5: Studies on the effect of internal parameters.

\begin{tabular}{|c|c|c|}
\hline Objectives & Result & References \\
\hline $\begin{array}{l}\text { The model can be built from mathematical equations and an } \\
\text { equivalent circuit consisting of a photogenerated current } \\
\text { source, a series resistor, a shunt resistor, and a diode. }\end{array}$ & $\begin{array}{l}\text { The I-V and P-V properties of SPV cells are also used in the } \\
\text { research of the effect; however, real-time simulations are } \\
\text { difficult to apply. }\end{array}$ & $\begin{array}{l}\text { Ahmed et al. } \\
\qquad[146]\end{array}$ \\
\hline $\begin{array}{l}\text { The performance of the Slider Mode Controller (SMC) is } \\
\text { substantially affected by the type of sliding surface used. }\end{array}$ & $\begin{array}{l}\text { The generic algorithm (GA) method was used for a more } \\
\text { realistic simulation of solar panels. }\end{array}$ & $\begin{array}{l}\text { Chatrenour } \\
\text { et al. [147] }\end{array}$ \\
\hline $\begin{array}{l}\text { The internal properties of a water-based SPV module are } \\
\text { examined using single diode models in comparison to land- } \\
\text { based SPV modules. }\end{array}$ & $\begin{array}{l}\text { The series resistance of water tank-based modules is higher } \\
\text { than that of land-based modules, according to data collected. }\end{array}$ & $\begin{array}{l}\text { Kumar and } \\
\text { Kumar [148] }\end{array}$ \\
\hline $\begin{array}{l}\text { Methodology for detecting photovoltaic system faults based } \\
\text { on the various I-V curve effects. }\end{array}$ & $\begin{array}{l}\text { Electrical parameters were examined, inflection spots in the } \\
\text { observed curve were tested using a learning technique, and a } \\
\text { fault's nature was discovered. }\end{array}$ & $\begin{array}{l}\text { Sarikh et al. } \\
\quad[149]\end{array}$ \\
\hline $\begin{array}{l}\text { SPV panel's performance parameters that are not generally } \\
\text { included in the manufacturer's specifications can be } \\
\text { determined via this modified algorithm method. }\end{array}$ & $\begin{array}{l}\text { In a comparison of the two algorithms, it is found that the } \\
\text { modified algorithm responds more accurately to sudden } \\
\text { increases in solar radiation. }\end{array}$ & $\begin{array}{l}\text { Motahhir } \\
\text { et al. }[150]\end{array}$ \\
\hline $\begin{array}{l}\text { An exhaustive review of the five most common fuzzy logic } \\
\text { subsets used in DC-DC boost converters. }\end{array}$ & $\begin{array}{l}\text { With the fewest oscillations and highest system efficiency, } \\
\text { the proposed subset can follow the maximum power point in } \\
\text { the least amount of time }(95.7 \%) \text {. }\end{array}$ & $\begin{array}{l}\text { Hajighorbani } \\
\text { et al. [151] }\end{array}$ \\
\hline $\begin{array}{l}\text { Reducing SPV modeling complexity and implementing a } \\
\text { simple fuzzy control system for duty cycle control were the } \\
\text { main objectives of this work. }\end{array}$ & $\begin{array}{l}\text { System tracking and dynamic response can be seen in the } \\
\text { graphical representation of the system's duty cycle in various } \\
\text { environmental conditions. }\end{array}$ & $\begin{array}{l}\text { Mahamudul } \\
\text { et al. [152] }\end{array}$ \\
\hline $\begin{array}{l}\text { An empirical model to predict the effect of temperature on } \\
\text { the outdoor performance of p-Si, } \mathrm{m}-\mathrm{Si} \text {, a-Si, and thin-film } \\
\text { SPV module technologies will be developed. }\end{array}$ & $\begin{array}{l}\text { The results show that the proposed model estimates can be } \\
\text { used to accurately and confidently predict the temperature of } \\
\text { SPV modules under similar environmental conditions to } \\
\text { those of the study area. SPV systems can be made more } \\
\text { efficient and cheaper as a result of this research. }\end{array}$ & $\begin{array}{l}\text { Jatoi et al. } \\
\quad[153]\end{array}$ \\
\hline $\begin{array}{l}\text { Impedance matching techniques are being used in this study } \\
\text { in an attempt to maximize the efficiency of SPV systems. }\end{array}$ & $\begin{array}{l}\text { It was found that SPV panel performance was highest when } \\
\text { the } 4 \Omega \text { electric load was in use for } 11 \text { of the month's } 12 \\
\text { measurement days, but on the final day, it performed worse } \\
\text { than the other two loads (the } 6 \Omega \text { and } 8 \Omega \text { electric loads) } \\
\text { when they were both in use. }\end{array}$ & $\begin{array}{l}\text { Salilih and } \\
\text { Birhane [154] }\end{array}$ \\
\hline
\end{tabular}

20\% for December, January, and February being the corresponding discrepancy between the total solar radiations.

The number of incidents of solar radiation in an SPV panel can represent various solar-cell fill-factor (FF) outputs as shown in Figure 14. The percentage level for fill factor in mono-Si and poly-Si materials is declining. In other instances, Copper Indium Selenide (CIS) substances will display a percentage increase in fill factor as the solar radiation level increases. It happens with the influence of the material thermal behavior of each solar cell. In this connection, polySi can be suitable for high solar radiation incident regions.

3.2. Effect of Temperature. Table 3 summarizes research on the impact of temperature on solar photovoltaic panels conducted by various researchers. In the first and last values, the average fill factor of the SPV module differed by approximately $22.98 \%, 54.16 \%$, and $26.19 \%$. The equivalent difference between the front and front photovoltaic average temperatures is $10.85 \%, 11.76 \%$, and $11.42 \%$ in December, January, and February (Figure 15). Here in January and then in February and December, a major difference of the fill factor and front side SPV module is achieved. Therefore, depending on climate change, the operating performance parameter degrades.
3.3. Effect of Relative Humidity. Table 4 summarizes research on the impact of relative humidity on solar photovoltaic panels conducted by various researchers. The resulting solar radiation is steadily decreased by increased relative average humidity on the panel's position [73]. The cumulative average relative humidity difference was approximately $35.71 \%$, $32.25 \%$, and $33.5 \%$, respectively, in January, December, and February (Figure 16).

3.4. Effect of Internal Parameters. Table 5 summarizes research by various studies on the impact of internal characteristic parameters on SPV cells. The SPV cell circuit for which the current is exponentially rising during the operating cycle is shown in Figure 17. The SPV cell's efficiency is determined also by the two resistors, namely, series and parallel resistors. A considerable amount of energy loss is normally attributed to manufacturing defections caused by the presence of parallel intensity in the SPV. The majority of the SPV cell has been optimized for a lower shunt resistance than the solar photovoltaic module would cause power loss because the lower resistance value is an alternative way for the circulation of the light current due to the lower power current. Lower load current declines the photovoltaic solar panel's output, which reduced the characteristics of fill 


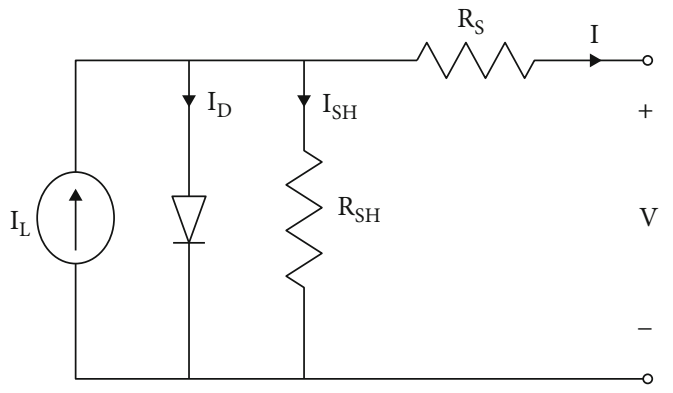

FIGURE 17: SPV cell equivalent circuit [175].

factor, power supply, and efficiency. The variance in solar radiation, therefore, plays an important part in the parasitic shunt resistance value that can affect performance. The equation for a solar cell when the shunt resistance is present [91] is as follows:

$$
I=I_{L}-I_{O} \exp \left(e^{q\left(V_{L}+I_{S} R_{S}\right)}-1\right)-\frac{V_{L}+I_{L} R_{S}}{R_{S H}} .
$$

A standard solar cell curve with different (constant) shunt resistance values is shown in Figure 18. Shunt resistances are named for $\mathrm{Rsh}_{1}(100 \Omega), \mathrm{Rsh}_{2}(200 \Omega), \mathrm{Rsh}_{3}$ $(300 \Omega), \operatorname{Rsh}_{4}(400 \Omega)$, and $\operatorname{Rsh}_{5}(500 \Omega)$ in this study. The shunt resistance varies drastically, but the voltage is slightly different. Increasing shunt resistance usually increases the point of peak power. Typically, the manufacturer determines the maximum voltage point and current values.

Figure 19 demonstrates the current and shunt resistance function of a typical short-circuit solar cell. The shunt resistors range from $1 \Omega$ to $10 \Omega$. As a consequence, shunt resistance is very low since the resulting short circuits have a low value. The shunt resistance for the short-circuit current is somewhat different because the effect of the short-circuit current is dependent on an individual material shape's boundary distance. A heavy material short circuit is present on the broadband distance. The maximum value is equal to the higher value in the short-circuit current.

The various losses with the percentage level of the SPV system are mentioned in Figure 19. The output is highly dependent on the module variability which includes the SPV array and solar cell modules. The difference between the highest possible output power from the array and the total output power of every module is called the incongruous losses.

\section{Different Topological Connections}

Table 6 summarizes research by various academics on the impact of different topological connections on solar photovoltaic modules. Comparisons of I-V properties of different network SPV modules demonstrate incompatible losses on an SPV device. The value of the voltage depends on the usual curve and form method. The temperature difference in the plug is due to incompatible conditions, the variation in the shading level, and the decrease in the connector cable voltage inside the network.

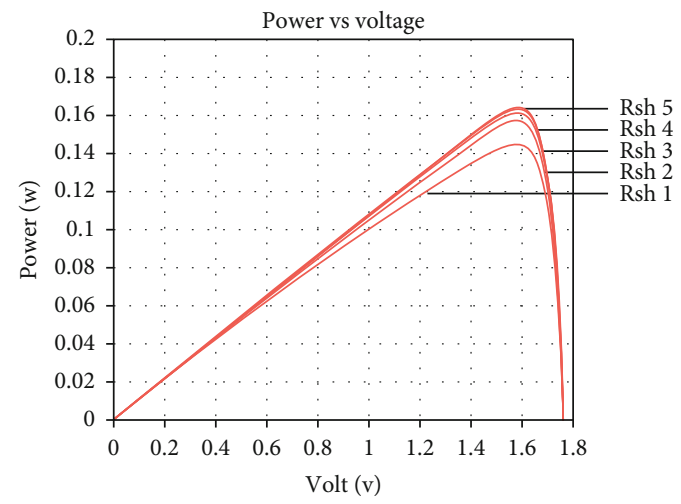

FIGURE 18: Power vs. voltage characteristic curve [91].

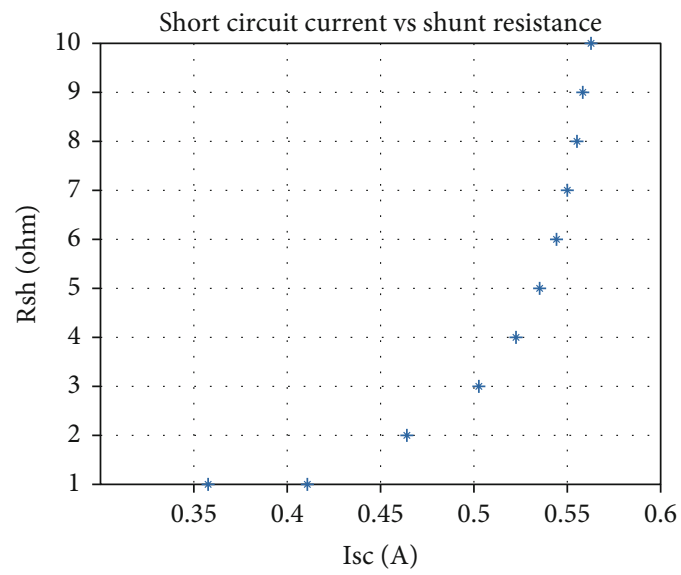

FIGURE 19: Short-circuit current vs. shunt resistance [91].

A mathematical model for the quantification of energy losses on the SPV system is designed because of the shaded effect. A shadowed portion of the total area and the number of connected blocks in the SPV system required for mathematical model analysis were considered, and the entire I-V curved system area was overlooked [92]. They predicted that power losses in a parallel range and sequence of $2 \%$ to $12 \%$ and $0.4 \%$ to $2.4 \%$ could be increased, respectively. The product of the user tolerances, environmental pressures, and cell's shadow effects are such power losses in an SPV cell. A single SPV model with various series and parallel SPVstring link schemes is designed for I-V and P-I [93].

\section{Applications}

A wide range of experts from academia, industry, and government are working to develop renewable energy sources for use in homes and the industrial sector. The losses must be reduced to obtain more energy from the SPV device; the system should be placed in a location sufficient to obtain high solar incident radiance, and the system should be properly maintained. While the shadow effects for rural electrification are taken into account, a model is developed combining a separate SPV module with an energy collection and control system [94]. 
TABLE 6: Studies on the effect of different topological connections.

\begin{abstract}
Objectives
Many different types of SPV array problems are discussed in this work, including the more frequent ones such as open circuits, shorts between lines, and ground faults.

New tempered glass-based SPV panels with $\mathrm{m}-\mathrm{Si}$ and $\mathrm{p}-\mathrm{Si}$ SPV cells will be tested experimentally to determine their electrical performance.

For the SPV system to which it is connected, each converter employs its MPPT algorithm. When subjected to uniform solar radiation, the operational voltage and power output of each panel tend to be equal under this topology.

Maximum power point tracking (MPPT) approaches and SPV system configurations are compared to increase the output of an SPV system in this article.

This paper presents a new architecture based on distinct generation characteristics for the integration of large-scale SPV plants into fragile networks.
\end{abstract}

This article presents and evaluates the SP, TCT BL, and HC configurations under partially shaded conditions.

For small-scale photovoltaic solar generation projects, residential complexes are ideal because they have sufficient space and large energy demand.

Direct Power Control (DPC) can be used to improve the quantity of solar power that is fed into the grid from a photovoltaic plant.

In this study, the floating photovoltaic (FPV) system is studied for its possible usage in Egypt's hydropower resources.

\section{Result}

It was found that a solar photovoltaic system's performance was affected by various fault conditions on SPV arrays of different topological configurations and fault conditions. A solar radiation level of $900 \mathrm{~W} / \mathrm{m}^{2}$ produced results of 67.4 W and 75.67 W from $\mathrm{p}-\mathrm{Si}$ and $\mathrm{m}-\mathrm{Si}$ SPV modules, respectively.

In both the simulation and the laboratory, the new strategy of comparing the electric properties of nearby SPV panels produced similar results for identifying partial shadow events. System performance was predicted to be in line with the design.

This study's findings show that intelligent techniques, as opposed to offline and online MPPT techniques, have greater future potential.

Weak grid integration can be better assessed with the proposed framework because it provides accurate voltage and energy estimates that have a high degree of reliability.

The array's generated power was found to be affected by the

type and amount of partially shaded modules. TCT configuration outperforms SP design when the shadow is oblique, as proven by the research results and findings.

According to the location where the study is taking place, the process and regulations for connecting a solar photovoltaic system to the energy endorsement firm in charge should be examined.

This system uses an MPPT (maximum power point tracking) technique-controlled DC-DC converter as its principal renewable source.

References

Lipták and

Bodnár [155]

Ding et al.

[156]

Raeisi and

Sadeghzadeh

[157]

Sharma et al. [158]

Saranchimeg and Nair

[159]

Kothari [160]

Muñoz et al. [161]

Zizoui et al. [162]

The researchers examined both fixed mounting and singleaxis tracking FPV, with the latter achieving a 4.96 percent greater energy rate. The combination of FPV technology with a hydrohybrid power system resulted in a 44,270.61-

Ravichandran et al. [163] tonne reduction in overall $\mathrm{CO}_{2}$ emissions.

Photovoltaic systems in particular are designed to fulfill the demands of industrial energy. However, the extensive reach of the building-integrated photovoltaic (BIPV) system linked to the building is being explored [95]. For every $1^{\circ} \mathrm{C}$ rise in the temperature of the SPV module, a decrease in power output of about $0.20-0.5 \%$ is observed. In a farreaching country in Nigeria, a hybrid solar photovoltaic/ thermal (SPV/T) system offering citizens social and economic opportunities to mitigate the problems that have increased electrical and thermal power generation has been mounted [96]. For different seasons, the plant ensures continuous and economic activity. Because of their high level of diesel price, the hybrid SPV/diesel battery systems are more economic than standalone diesel systems. When considering factors like interest rate and load sizes for a system, the hybrids SPV/diesel are more effective than standalone diesel [97-104].

SPV module measures the effect of the temperatures on electrical parameter output according to Standard Conditions of Testing and outdoor climate (less than $500 \mathrm{~W} / \mathrm{m}^{2}$ ). For each $1^{\circ} \mathrm{C}$ rise in the temperature of the SPV module, the loss of power in the outside and STC is 0.48 and $0.52 \%$
[105]. For freely installed systems with specific environmental and numerical parameters, the extensive temperature literature of the SPV module has been used. Appropriate correlations should therefore be selected and implemented at various SPV module sites [106]. In superior SPV modules, estimated variations in power and efficiency parameters examined the effect of ambient temperatures between $25^{\circ} \mathrm{C}$ to $50^{\circ} \mathrm{C}$. The ambient temperature of the SPV module was up to $0.50 \%$ per ${ }^{\circ} \mathrm{C}$ and $0.05 \%$ per ${ }^{\circ} \mathrm{C}$, respectively, as a considerable decrease in corresponding energy and effectiveness [107, 108].

\section{Merits and Demerits of the SPV System}

It is more difficult to build, install, and design because of the potential for more backside shade, but its unusual structure produces 5-30 percent more power output and 2-6\% cheaper LCOE due to its ability to absorb solar energy from both sides. UV rays from the ground break down typical organic back sheets, and water vapor seeps in through gaps and holes to cause functional failure. A lower cleaning frequency and longer lifetime are achieved with SPV modules 
Table 7: Merits and demerits of the photovoltaic system.

\begin{tabular}{|c|c|c|}
\hline Merits & Demerits & References \\
\hline $\begin{array}{l}\text { Because of its lower operating costs, the solar energy industry is } \\
\text { growing rapidly around the world. } \\
\text { There are two stages to TCT: the modules are connected in } \\
\text { parallel and subsequently connected in series. To conserve } \\
\text { money, only four modules are cross-tied together in BL, which } \\
\text { is a significant reduction. TCT and BL combine to form HC. } \\
\text { Depending on how many cross-ties it has (either two, four, or } \\
\text { six), it can give the necessary power. }\end{array}$ & $\begin{array}{c}\text { Photovoltaic systems have the major drawback of being } \\
\text { completely dependent on changes in solar radiation for their } \\
\text { output power. } \\
\text { Nevertheless, SPV suffers from partial shading due to a } \\
\text { mismatching condition. }\end{array}$ & $\begin{array}{c}\text { Nayak } \\
\text { et al. [164] }\end{array}$ \\
\hline
\end{tabular}

TABle 8: Merits and demerits of various topological connections [165-169].

\begin{tabular}{|c|c|c|}
\hline Configuration & Merits & Demerits \\
\hline SP & $\begin{array}{l}\text { (i) Under the same circumstances, it is effective } \\
\text { (ii) Cost-effectiveness } \\
\text { (iii) Low level of difficulty }\end{array}$ & $\begin{array}{l}\text { (i) SP is more sensitive to radiation levels than other } \\
\text { devices, and the power decreases dramatically when } \\
\text { partially shaded } \\
\text { (ii) Partially shaded areas will not be covered }\end{array}$ \\
\hline $\mathrm{BL}$ & $\begin{array}{l}\text { (i) With partial shading, this is suitable } \\
\text { (ii) In comparison to SP, the maximum power output of } \mathrm{BL} \text { is } \\
2.5 \% \text { higher } \\
\text { (iii) During periods of partial shading, keep recharging the grid }\end{array}$ & $\begin{array}{l}\text { (i) The level of difficulty is moderate } \\
\text { (ii) Inadequate effectiveness }\end{array}$ \\
\hline TCT & $\begin{array}{l}\text { (i) Possible with some shading } \\
\text { (ii) TCT has superior performance, is less susceptible to partial } \\
\text { shading, is more dependable, and has higher peak power values } \\
\text { and efficiency } \\
\text { (iii) During partial shading, keep feeding the grid }\end{array}$ & $\begin{array}{l}\text { TCT has the most connections and is more difficult to } \\
\text { implement than other configurations }\end{array}$ \\
\hline $\mathrm{HC}$ & $\begin{array}{l}\text { (i) With partial shade, this is a viable option } \\
\text { (ii) MPP improvement on a medium scale } \\
\text { (iii) During partial darkening, keep feeding the grid }\end{array}$ & $\begin{array}{l}\text { (i) Moderately difficult } \\
\text { (ii) Moderate efficiency }\end{array}$ \\
\hline
\end{tabular}

using classic glass organic back sheet architectures compared with those using SPV modules with a lower cell temperature and a more robust resistance to unfavorable environmental conditions. Table 7 summarizes research by various academics on the merits and demerits of solar photovoltaic systems. Table 8 summarizes research by various academics on the merits and demerits of various topological connections on solar photovoltaic modules [109-113].

\section{Conclusions}

The mismatch loss of the SPV system was analyzed in the influence of performance parameters, including internal and external conditions. The influence of internal parameters like parasitic shunt resistance of different ranges was used in SPV cells, and also, the impact on current-voltage characteristics was studied. The selection of different SPV materials ( $\mathrm{m}-\mathrm{Si}$ and $\mathrm{p}-\mathrm{Si}$ ) and external environmental parameters (solar radiation, temperature, relative humidity, and dust) was considered to evaluate the performance of the system. As far as the present review is concerned, it was aimed at discussing in detail the influences of the parameters mentioned above on the performance of the SPV system. Different topological connections (SS, SP, TCT, BL, and HC) were also considered, and further, TCT configuration was promised to be an improved technique of enhancing performance under influence of partial shading conditions. Similarly, studies on numerous researchers' findings were presented in tables. Recent techniques, circuit implementation for reducing the impact of partial shading, and merits and demerits were discussed. This review covered the indispensable subjects of the causes and effects of mismatch losses and mitigating techniques to the mismatch losses, elaborately. Thus, this review could pave a path for aspiring researchers to attempt numerous analytical and experimental studies, in order to find innovative practices to address the issues existing in external and internal parameters, and thereby, the energy conversion value of the SPV system could be improved remarkably.

\section{Nomenclature}

AC: Alternating current

BIPV: Building-integrated photovoltaics

BL: $\quad$ Bridge link

CdTe: Cadmium telluride

CFD: Computational Fluid Dynamics

CIGS: Copper indium gallium selenide

CIS: Copper Indium Selenide

CTM: Cell to Module

DC: $\quad$ Direct current

DPC: Direct Power Control

FF: $\quad$ Fill factor

FPV: Floating photovoltaic 
GaAs: Gallium Arsenide

HC: Honeycomb

HEL: Hole Extraction Layer

I: $\quad$ Cell output current (A)

$I_{L}: \quad$ Light generated current (A)

$I_{O}: \quad$ Diode darkness current (A)

$I_{S}: \quad$ Current across series resistance (A)

I-V: Current-voltage

LPB: Long parallel branch

LCOE: Levelized Cost of Electricity

LSS: Long series string

MML: Mismatch loss

MPP: Maximum power point

MPPT: Maximum power point tracking

m-Si: Monocrystalline

p-Si: Polycrystalline

P-V: $\quad$ Power-voltage

$P_{\text {Array }}$ : Solar photovoltaic array power

$P_{\text {Cell }}: \quad$ Solar photovoltaic cell power

$q$ : $\quad$ Electron charge $\left(1.602 \times 10^{-19} \mathrm{c}\right)$

$R_{S H}: \quad$ Cell shunt resistance $(\Omega)$

Rs: $\quad$ Series resistance $(\Omega)$

SDK: So-du-Ku

SP: $\quad$ Series parallel

SPDK: Shape-do-Ku

SPV: Solar photovoltaic

SS: $\quad$ Simple series

SPV/T: Solar photovoltaic/thermal

TCT: Total cross-tied

$V_{L}$ : $\quad$ Voltage across the cell terminals (V).

\section{Conflicts of Interest}

The authors declare that they have no conflicts of interest.

\section{References}

[1] D. Picault, B. Raison, S. Bacha et al., "Forecasting photovoltaic array power production subject to mismatch losses," Solar Energy, vol. 84, no. 7, pp. 1301-1309, 2010.

[2] J. Guerrero, Y. Munoz, F. C. Ibanez, and A. Ospino, "Analysis of mismatch and shading effects in a photovoltaic array using different technologies," Materials Science and Engineering, vol. 59, no. 1, article 012007, 2014.

[3] J. Webber and E. Riley, "Mismatch loss reduction in photovoltaic arrays as a result of sorting photovoltaic modules by max-power parameters," ISRN Renewable Energy, vol. 2013, Article ID 327835, 9 pages, 2013.

[4] N. D. Kaushika and A. K. Rai, "An investigation of mismatch losses in solar photovoltaic cell networks," Energy, vol. 32, no. 5 , p. $755,2007$.

[5] D. Roche, H. Outhred, R. J. Kaye, and R. J. Kaye, "Analysis and control of mismatch power loss in photovoltaic arrays," Progress in Photovoltaics: Research and Applications, vol. 3, no. 2, pp. 115-127, 1995.

[6] S. Vijayalekshmy, G. R. Bindu, and S. Rama Iyer, "Estimation of power loss in photovoltaic array configurations under passing cloud condition," in Proceedings of the World Congress on Engineering, vol. 1, pp. 1-6, Cochin, India, 2014.
[7] D. Picault, B. Raison, S. Bacha, J. Aguilera, and J. De La Casa, "Changing photovoltaic array interconnections to reduce mismatch losses: a case study," in 2010 9th International Conference on Environment and Electrical Engineering, pp. 37-40, Prague, Czech Republic, 2010.

[8] H. Obane, K. Okajima, T. Ozeki, and T. Ishii, "PV system with reconnection to improve output under non-uniform illumination," IEEE Journal of Photovoltaics, vol. 2, no. 3, pp. 341-347, 2012.

[9] S. R. Potnuru, D. Pattabiraman, S. I. Ganesan, and N. Chilakapati, "Positioning of PV panels for reduction in line losses and mismatch losses in PV array," Renewable Energy, vol. 78, pp. 264-275, 2015.

[10] J. L. Crozer, E. E. Van Dyk, and F. J. Vorster, "Characterization of cell mismatch in a multi-crystalline silicon photovoltaic module," Physica B, vol. 407, no. 10, pp. 1578-1581, 2012.

[11] S. Edalati, M. Ameri, and M. Iranmanash, "Comparative performance investigation of mono- and poly-crystalline silicon photovoltaic modules for use in grid-connected photovoltaic systems in dry climates," Applied Energy, vol. 160, pp. 255265, 2015.

[12] I. Visa, B. Burduhos, M. Neagoe, M. Moldovan, and A. Duta, "Comparative analysis of the infield response of five types of photovoltaic modules," Renewable Energy, vol. 95, pp. 178190, 2016.

[13] E. Karatepe, M. Boztepe, and M. Colak, "Development of a suitable model for characterizing photovoltaic arrays with shaded solar cells," Solar Energy, vol. 81, no. 8, pp. 977-992, 2007.

[14] G. Petrone, G. Spagnuolo, and M. Vitelli, “Analytical model of mismatched photovoltaic fields by means of Lambert Wfunction," Solar Energy Materials \& Solar Cells, vol. 91, no. 18, pp. 1652-1657, 2007.

[15] W. R. Anis and M. Abdul-Sadek Nour, "Energy losses in photovoltaic systems," Energy Conservation and Management, vol. 36, no. 11, pp. 1107-1113, 1995.

[16] V. Tyagi, N. A. Rahim, N. Rahim, A. Jeyraj, and L. Selvaraj, "Progress in solar PV technology: research and achievement," Renewable and Sustainable Energy Review, vol. 20, pp. 443461, 2013.

[17] M. A. Green, "Thin-film solar cells: review of materials, technologies and commercial status," Journal of Material Science: Materials in Electronics, vol. 18, no. S1, pp. 15-19, 2007.

[18] K. Kawashima, Y. Tamai, H. Ohkita, I. Osaka, and K. Takimiya, "High-efficiency polymer solar cells with small photon energy loss," Nature Communications, vol. 6, no. 1, 2015.

[19] J. Kim, Z. Hong, G. Li et al., "10.5\% efficient polymer and amorphous silicon hybrid tandem photovoltaic cell," Nature Communications, vol. 6, no. 1, 2015.

[20] A. N. B. Zulkifili, T. Kento, M. Daiki, and A. Fujiki, "The basic research on the dye-sensitized solar cells (DSSC)," Journal of Clean Energy Technologies, vol. 3, no. 5, pp. 382-387, 2015.

[21] C. Ferrara and D. Philipp, "Why do PV modules fail," Energy Procedia, vol. 15, pp. 379-387, 2012.

[22] B. Norton, P. C. Eames, T. K. Mallick et al., "Enhancing the performance of building integrated photovoltaics," Solar Energy, vol. 85, no. 8, pp. 1629-1664, 2011.

[23] R. B. Sathyanarayana, P. S. Lakshmi Sagar, and G. Kumar, "Effect of shading on the performance of solar PV panel," Energy and Power, vol. 5, no. 1A, 2015. 
[24] S. Motasem, A. G. Albaali, E. Alasis, and J. K. Kaldellis, "Experimental study on the effect of dust deposition on solar photovoltaic panels in desert environment," Renewable Energy, vol. 92, pp. 499-505, 2016.

[25] M. Hosenuzzaman, N. A. Rahim, J. Selvaraj, and M. Hasanuzzaman, "Factors affecting the PV based power generation," in 3rd IET International Conference on Clean Energy and Technology (CEAT) 2014, pp. 1-6, Kuching, 2014.

[26] S. Kumar and T. Kaur, "Solar PV performance-issues and challenges," International Journal of Innovative Research in Electrical, Electronics, Instrumentation and Control Engineering, vol. 2, no. 11, pp. 2168-2172, 2014.

[27] A. Al-Otaibi, A. Al-Qattan, F. Fairouz, and A. Al-Mulla, "Performance evaluation of photovoltaic systems on Kuwaiti schools' rooftop," Energy Conversion and Management, vol. 95, pp. 110-119, 2015.

[28] D. Martinez-Plaza, A. Abdallah, B. W. Figgis, and T. Mirza, "Performance improvement techniques for photovoltaic systems in Qatar: results of first year of outdoor exposure," Energy Procedia, vol. 77, pp. 386-396, 2015.

[29] M. R. Maghami, H. Hizam, C. Gomes, M. A. Radzi, M. I. Rezadad, and S. Hajighorbani, "Power loss due to soiling on solar panel: a review," Renewable, and Sustainable Energy Reviews, vol. 59, pp. 1307-1316, 2016.

[30] M. Vazquez and I. Rey-Stolle, "Photovoltaic module reliability model based on field degradation studies," Progress in Photovoltaics: Research and Applications, vol. 16, no. 5, pp. 419-433, 2008.

[31] A. Ndiaye, C. M. F. Kebe, P. A. Ndiaye, A. Charki, A. Kobi, and V. Sambou, "Impact of dust on the photovoltaic (PV) modules characteristics after an exposition year in Sahelian environment: the case of Senegal," International Journal of Physical Sciences, vol. 8, no. 21, pp. 1166-1173, 2013.

[32] T. Ma, H. Yang, and L. Lin, "Development of a model to simulate the performance characteristics of crystalline silicon photovoltaic modules/strings/arrays," Solar Energy, vol. 100, pp. 31-41, 2014.

[33] J. D. Bastidas, E. Franco, G. Petrone, C. A. Ramos-Paja, and G. Spagnuolo, "A model of photovoltaic fields in mismatching conditions featuring an improved calculation speed," Electrical Power System Research, vol. 96, pp. 81-90, 2013.

[34] M. R. Al Rashidi, K. M. El-Naggar, and M. F. Al Hajri, "Parameters estimation of double diode solar cell model," International Journal of Electrical, Computer, Energetic, Electronic and Communication Engineering, vol. 7, no. 2, pp. 118121, 2013.

[35] J. Surya Kumara and S. B. Ch, "Mathematical modeling and simulation of photovoltaic cell using matlab-simulink environment," International Journal of Electrical and Computer Engineering, vol. 2, no. 1, pp. 26-34, 2012.

[36] J.-C. Wang, J.-C. Shieh, S. Yu-Li et al., "A novel method for the determination of dynamic resistance for photovoltaic modules," Energy, vol. 36, no. 10, pp. 5968-5974, 2011.

[37] A. Al Tarabsheh, I. Etier, and M. Widyan, "Investigation of the shunt effects of parallel-connected a-Si: H solar cells," International Journal of Sustainable Energy, vol. 32, no. 2, pp. 71-77, 2011.

[38] Y. S. Kim, S.-M. Kang, B. Johnston, and R. Winston, “A novel method to extract the series resistances of individual cells in a photovoltaic module," Solar Energy Materials \& Solar Cells, vol. 115, pp. 21-28, 2013.
[39] C. S. Ruschel, F. P. Gasparin, E. R. Costa, and A. Krenzinger, "Assessment of PV modules shunt resistance dependence on solar irradiance," Solar Energy, vol. 133, pp. 35-43, 2016.

[40] D. Rusirawan and I. Farkas, "Identification of model parameters of the photovoltaic solar cells," Energy Procedia, vol. 57, pp. 39-46, 2014.

[41] M. S. Benghanem and S. N. Alamri, "Modeling of photovoltaic module and experimental determination of serial resistance," Journal of Taibah University for Science, vol. 2, no. 1, pp. 94-105, 2009.

[42] F. Ghani, M. Duke, and J. Carson, "Numerical calculation of series and shunt resistance of a photovoltaic cell using the Lambert $W$-function: Experimental evaluation," Solar Energy, vol. 87, pp. 246-253, 2013.

[43] F. Ghani and M. Duke, "Numerical determination of parasitic resistances of a solar cell using the Lambert w-function," Solar Energy, vol. 85, no. 9, pp. 2386-2394, 2011.

[44] C. Carrero, J. Rodríguez, D. Ramírez, and C. Platero, "Simple estimation of pv modules loss resistances for low error modelling," Renewable Energy, vol. 35, no. 5, pp. 11031108, 2010.

[45] A. Rezaee Jordehi, "Parameter estimation of solar photovoltaic (PV) cells: a review," Renewable and Sustainable Energy Reviews, vol. 61, pp. 354-371, 2016.

[46] H.-H. Hseih, F.-M. Lin, and Y. Shan-Pu, "Performance of low series-resistance interconnections on the polycrystalline solar cells," Solar Energy Materials \& Solar Cells, vol. 95, no. 1, pp. 39-44, 2011.

[47] J. Bastidas, C. Y. Ramos, and E. Franco, "Modelling and parameter calculation of photovoltaic fields in irregular weather conditions," En: Ingenieria, vol. 17, no. 1, pp. 3748, 2012

[48] F. Sarhaddi, S. Farahat, H. Ajam, A. Behzadmehr, and M. Mahdavi Adeli, "An improved thermal and electrical model for a solar photovoltaic thermal (PV/T) air collector," Applied Energy, vol. 87, no. 7, pp. 2328-2339, 2010.

[49] R. Guliani, A. Jain, S. Sharma, D. Kaur, A. Guliani, and A. Kapoor, "Analysis of electrical characteristics using a Lambert W-function technique and MATLAB simulation for dye sensitised $\mathrm{ZnO}$ solar cell," The Open Renewable Energy Journal, vol. 6, pp. 23-28, 2010.

[50] R. Dash and S. M. Ali, "Comparative study of one and two diode model of solar photovoltaic cell," International Journal of Research in Engineering and Technology, vol. 3, no. 10, pp. 190-194, 2014.

[51] Y. Chen, X. W. Da Li, R. Hong, and H. Shen, "Parameters extraction from commercial solar cells $I-V$ characteristics and shunt analysis," Applied Energy, vol. 88, no. 6, pp. 2239-2244, 2011.

[52] E. Radziemska, "Thermal performance of $\mathrm{Si}$ and GaAs based solar cells and modules: a review," Progress in Energy and Combustion Science, vol. 29, no. 5, pp. 407-424, 2003.

[53] V. K. Sethi, M. Pandey, and P. Shukla, "Thin-film photovoltaic cell compared to mono crystalline photovoltaic cell and multi crystalline photovoltaic cell," International Journal of Advanced Renewable Energy Research, vol. 1, no. 2, pp. 117125, 2012.

[54] M. R. Abdelkader, A. Al-Salaymeh, Z. Al-Hamamre, and F. Sharaf, "A comparative analysis of the performance of monocrystalline and multicrystalline PV cells in semi arid climate conditions: the case of Jordan," Jordan Journal of 
Mechanical and Industrial Engineering, vol. 4, no. 5, pp. 543552, 2010.

[55] M. A. Mosalam Shaltout, A. A. El-Hadad, M. A. Fadly, A. F. Hassan, and A. M. Mahrous, "Determination of suitable types of solar cells for optimal outdoor performance in desert climate," Renewable Energy, vol. 19, no. 1-2, pp. 71-74, 2000.

[56] A. Hunter Fanney, M. W. Davis, B. P. Dougherty, D. L. King, W. E. Boyson, and J. A. Kratochvil, "Comparison of photovoltaic module performance measurements," Journal of Solar Energy Engineering, vol. 128, no. 2, pp. 152-159, 2006.

[57] M. Azhar Ghazali, A. Malek, and A. Rahman, "The performance of three different solar panels for solar electricity applying solar tracking device under the Malaysian climate condition," Energy and Environment Research, vol. 2, no. 1, pp. 235-243, 2012.

[58] O.-M. Midtgard, T. O. Saetre, G. Yordanov, A. G. Imenes, and C. L. Nge, "A qualitative examination of performance and energy yield of photovoltaic modules in southern Norway," Renewable Energy, vol. 35, no. 6, pp. 1266-1274, 2010.

[59] A. Limmanee, N. Udomdachanut, S. Songtrai et al., "Field performance and degradation rates of different types of photovoltaic modules: a case study in Thailand," Renewable Energy, vol. 89, pp. 12-17, 2016.

[60] F. Dincer and M. E. Merat, "Critical factors that affecting efficiency of solar cells," Smart Grid and Renewable Energy, vol. 1, no. 1, pp. 47-50, 2010.

[61] R. Siddiqui and U. Bajpai, "Correlation between thicknesses of dust collected on photovoltaic module and difference in efficiencies in composite climate," International Journal of Renewable Energy Research, vol. 3, no. 1, pp. 26-490, 2012.

[62] C. Min, "Analysis about modules and strings mismatch loss in the photovoltaic plant," American Journal of Modern Energy, vol. 5, no. 3, pp. 63-68, 2019.

[63] A. Gholami, M. Ameri, M. Zandi, and R. G. Ghoachani, "Electrical, thermal and optical modeling of photovoltaic systems: step-by-step guide and comparative review study," Sustainable Energy Technologies and Assessments, vol. 49, article 101711, 2022.

[64] A. Hussain, A. Batra, and R. Pachauri, "An experimental study on effect of dust on power loss in solar photovoltaic module," Renewables: Wind, Water, and Solar, vol. 4, no. 1, pp. 1-13, 2017.

[65] T. Sarver, A. Al-Qaraghuli, and L. L. Kazmerski, "A comprehensive review of the impact of dust on the use of solar energy: history, investigations, results, literature, and mitigation approaches," Renewable and Sustainable Energy Reviews, vol. 22, pp. 698-733, 2013.

[66] T. Khatib, H. Kazem, K. Sopian, F. Buttinger, W. Elmenreich, and A. S. Albusaidi, "Effect of dust deposition on the performance of multi-crystalline photovoltaic modules based on experimental measurements," International Journal of Renewable Energy Research, vol. 3, no. 4, pp. 850-853, 2013.

[67] Y. Andrea, T. Pogrebnaya, and B. Kichonge, "Effect of industrial dust deposition on photovoltaic module performance: experimental measurements in the tropical regionInternational Journal of Photoenergy," vol. 2019, Article ID 1892148, 10 pages, 2019.

[68] M. Konyu, N. Ketjoy, and C. Sirisamphanwong, "Effect of dust on the solar spectrum and electricity generation of a photovoltaic module," IET Renewable Power Generation, vol. 14, no. 14, pp. 2759-2764, 2020.
[69] https://blog.aurorasolar.com/understanding-pv-systemlosses-part-1.

[70] L. L. Bucciarelli Jr., "Power loss in photovoltaic arrays due to mismatch in cell characteristics," Solar Energy, vol. 23, no. 4, pp. 277-288, 1979.

[71] C. Deline, S. A. Pelaez, S. MacAlpine, and C. Olalla, Bifacial $P V$ system mismatch loss estimation and parameterization: preprint, National Renewable Energy Laboratory. NREL/ CP-5K00-73541, Golden, CO, 2019, https://www.nrel.gov/ docs/fy20osti/73541.pdf.

[72] M. B. MacAlpine and R. Erickson, "Quantifying mismatch losses in small arrays," in 2013 Sandia PV Performance Modeling Workshop, Santa Clar, CA, 2013.

[73] T. Selmi and A. Gastli, "Grid-connected photovoltaic system requirement," Peer Review Journal of Solar \& Photoenergy Systems, vol. 1, 2018.

[74] D. Avithi Desappan, E. Natarajan, and L. Ponnusamy, "Performance evaluation of photovoltaic system in humid atmosphere," in Applied Mechanics and Materials, vol. 787, pp. 57-61, Trans Tech Publications Ltd., 2015.

[75] N. HemanthBabu, S. Shivashimpiger, N. Samanvita, and V. M. Parthasarathy, "Performance ratio and loss analysis for 20MW grid connected solar PV system-case study," International Journal of Engineering and Advanced Technology, vol. 8, no. 2S2, 2019.

[76] M. Mutluer and A. Erat, "A new intelligent system design for cleaning the photovoltaic solar panel surface," International Journal of Energy Applications and Technologies, vol. 6, no. 1, pp. 8-16.

[77] E. Bellini, "Pv magazine," PV magazine, vol. 2, 2017.

[78] A. A. Mansur, M. Amin, and K. K. Islam, "Performance comparison of mismatch power loss minimization techniques in series-parallel PV array configurations," Energies, vol. 12, no. 5, p. 874, 2019.

[79] S. Ekici and M. A. Kopru, "Investigation of PV system cable losses," International journal of renewable energy research, vol. 7, no. 2, pp. 807-815, 2017.

[80] K. Lappalainen and S. Valkealahti, "Photovoltaic mismatch losses caused by moving clouds," Solar Energy, vol. 158, pp. 455-461, 2017.

[81] S. Pannientakandi, R. Gupta, and S. Manjoli, "Effect of local shunting on the electrical mismatch losses in industrial silicon photovoltaic modules," International Journal of Power and Energy Research, vol. 2, no. 1, pp. 1-15, 2018.

[82] N. Rakesh, S. Banerjee, S. Subramaniam, and N. Babu, "A simplified method for fault detection and identification of mismatch modules and strings in a grid-tied solar photovoltaic system," International Journal of Emerging Electric Power Systems, vol. 21, no. 4, 2020.

[83] A. Khatibi, F. Razi Astaraei, and M. H. Ahmadi, "Generation and combination of the solar cells: a current model review," Energy Science \& Engineering, vol. 7, no. 2, pp. 305-322, 2019.

[84] S. Chander, A. Purohit, A. Sharma, S. P. Nehra, and M. S. Dhaka, "A study on photovoltaic parameters of monocrystalline silicon solar cell with cell temperature," Energy Reports, vol. 1, pp. 104-109, 2015.

[85] R. K. Pachauri, I. Kansal, T. S. Babu, and H. H. Alhelou, "Power losses reduction of solar PV systems under partial shading conditions using re-allocation of PV module-fixed electrical connections," IEEE Access, vol. 9, pp. 9478994812, 2021. 
[86] G. Madhusudanam, S. Senthilkumar, I. Anand, and P. Sanjeevkumar, "A shade dispersion scheme using Latin square arrangement to enhance power production in solar photovoltaic array under partial shading conditions," Journal of Renewable and Sustainable Energy, vol. 10, no. 5, pp. 1-14, 2018.

[87] A. Srinivasan, S. Devakirubakaran, and B. M. Sundaram, "Mitigation of mismatch losses in solar PV system -twostep reconfiguration approach," Solar Energy, vol. 206, pp. 640-654, 2020.

[88] G. Rezk, A. Fathy, and M. Aly, "A robust photovoltaic array reconfiguration strategy based on coyote optimization algorithm for enhancing the extracted power under partial shadow condition," Energy Reports, vol. 7, pp. 109-124, 2021.

[89] R. Venkateswari and N. Rajasekar, "Power enhancement of PV system via physical array reconfiguration based Lo Shu technique," Energy Conversion and Management, vol. 215, article 112885, 2020.

[90] J. J. Wanko and J. V. Nickell, "Reinforcing geometric properties with Shapedoku puzzles," Mathematics Teacher, vol. 107, no. 3, pp. 188-194, 2013.

[91] A. D. Dhass, E. Natarajan, and L. Ponnusamy, "Influence of shunt resistance on the performance of the solar photovoltaic cells," in 2012 International Conference on Emerging Trends in Electrical Engineering and Energy Management (ICETEEEM), pp. 382-386, Chennai, India, 2012.

[92] F. Martinez-Mareno, J. Munoz, and E. Lorenzo, "Experimental model to estimate shading losses on PV arrays," Solar Energy Materials \& Solar Cells, vol. 94, no. 12, pp. 2298-2303, 2010.

[93] H. Tian, F. Mancilla-David, K. Ellis, E. Muijadi, and P. Jenkins, "A cell-to-module-to-array detailed model for photovoltaic panels," Solar Energy, vol. 86, no. 9, pp. 26952706, 2012.

[94] W. Grzesiak, P. Mackow, T. Maj et al., "Innovative system for energy collection and management integrated within a photovoltaic module," Solar Energy, vol. 132, pp. 442-452, 2016.

[95] W. Zheng, H. Bin, L. Nianping, L. Shan, and Y. Chunni, "Investigation on photovoltaic application in buildings in China," Energy Procedia, vol. 70, pp. 673-682, 2015.

[96] A. Makki, S. Omer, and H. Sabir, "Advancements in hybrid photovoltaic systems for enhanced solar cells performance," Renewable and Sustainable Energy Reviews, vol. 41, pp. 658-684, 2015.

[97] D. O. Akinyele, R. K. Rayudu, and N. K. C. Nair, "Development of photovoltaic power plant for remote residential applications: the socio-technical and economic perspectives," Applied Energy, vol. 155, pp. 131-149, 2015.

[98] K. Y. Lau, C. W. Tan, and A. H. M. Yatim, "Photovoltaic systems for Malaysian islands: effects of interest rates, diesel prices and load sizes," Energy, vol. 83, pp. 204-216, 2015.

[99] K. E. Park, G. H. Kang, H. I. Kim, G. J. Yu, and J. T. Kim, "Analysis of thermal and electrical performance of semitransparent photovoltaic (PV) module," Energy, vol. 35, no. 6, pp. 2681-2687, 2010.

[100] E. Skoplaki and J. A. Palyvos, "Operating temperature of photovoltaic modules: a survey of pertinent correlations," Renewable Energy, vol. 34, no. 1, pp. 23-29, 2009.

[101] J. P. Kim, J. Ho Lim, H. Song, Y. J. Chnag, and C. H. Jeon, "Numerical analysis on the thermal characteristics of photovoltaic module with ambient temperature variation," Solar Energy Materials \& Solar Cells, vol. 95, no. 1, pp. 404-407, 2011.
[102] M. M. Fouad, L. A. Shihata, and E. I. Morgan, “An integrated review of factors influencing the perfomance of photovoltaic panels," Renewable and Sustainable Energy Reviews, vol. 80, pp. 1499-1511, 2017.

[103] H. Ali and H. A. Khan, "Analysis on inverter selection for domestic rooftop solar photovoltaic system deployment," International Transactions on Electrical Energy Systems, vol. 30, no. 5, article e12351, 2020.

[104] K. R. McIntosh, M. D. Abbott, B. A. Sudbury, and J. Meydbray, "Mismatch loss in bifacial modules due to nonuniform illumination in 1-D tracking systems," IEEE Journal of Photovoltaics, vol. 9, no. 6, pp. 1504-1512, 2019.

[105] S. K. Cherukuri, P. K. Balachandran, K. R. Kaniganti et al., "Power enhancement in partial shaded photovoltaic system using spiral pattern array configuration scheme," IEEE Access, vol. 9, pp. 123103-123116, 2021

[106] R. Evans, M. Boreland, and M. A. Green, "A holistic review of mismatch loss: from manufacturing decision making to losses in fielded arrays," Solar Energy Materials and Solar Cells, vol. 174, pp. 214-224, 2018.

[107] A. Srinivasan, S. Devakirubakaran, and B. M. Sundaram, "Mitigation of mismatch losses in solar PV system - Twostep reconfiguration approach," Solar Energy, vol. 206, pp. 640-654, 2020.

[108] P. R. Satpathy, S. Jena, and R. Sharma, "Power enhancement from partially shaded modules of solar PV arrays through various interconnections among modules," Energy, vol. 144, pp. 839-850, 2018.

[109] X. Sun, M. R. Khan, C. Deline, and M. A. Alam, "Optimization and performance of bifacial solar modules: a global perspective," Applied Energy, vol. 212, pp. 1601-1610, 2018.

[110] M. T. Patel, M. R. Khan, X. Sun, and M. A. Alam, "A worldwide cost-based design and optimization of tilted bifacial solar farms," Applied Energy, vol. 247, pp. 467-479, 2019.

[111] C. D. Rodríguez-Gallegos, M. Bieri, O. Gandhi, J. P. Singh, T. Reindl, and S. K. Panda, "Monofacial vs bifacial Si-based PV modules: which one is more cost-effective?," Solar Energy, vol. 176, pp. 412-438, 2018.

[112] B. Yu, D. Song, Z. Sun et al., "A study on electrical performance of N-type bifacial PV modules," Solar Energy, vol. 137, pp. 129-133, 2016.

[113] J. S. Stein, D. Riley, M. Lave, C. Hansen, C. Deline, and F. Toor, "Outdoor field performance from bifacial photovoltaic modules and systems," in 2017 IEEE 44th Photovoltaic Specialist Conference (PVSC), pp. 3184-3189, Washington, DC, USA, 2017.

[114] B. Dhanalakshmi and N. Rajasekar, "Dominance square based array reconfiguration scheme for power loss reduction in solar PhotoVoltaic (PV) systems," Energy Conversion and Management, vol. 156, pp. 84-102, 2018.

[115] D. G. Lorente, S. Pedrazzi, G. Zini, A. Dalla Rosa, and P. Tartarini, "Mismatch losses in PV power plants," Solar Energy, vol. 100, pp. 42-49, 2014.

[116] P. Rodrigo, R. Velázquez, E. F. Fernández, F. Almonacid, and P. J. Pérez-Higueras, "Analysis of electrical mismatches in high-concentrator photovoltaic power plants with distributed inverter configurations," Energy, vol. 107, pp. 374387, 2016.

[117] V. Sharma and S. S. Chandel, "Performance analysis of a 190 kWp grid interactive solar photovoltaic power plant in India," Energy, vol. 55, pp. 476-485, 2013. 
[118] A. Wang and Y. Xuan, "A detailed study on loss processes in solar cells,” Energy, vol. 144, pp. 490-500, 2018.

[119] A. K. Tripathi, S. Ray, and M. Aruna, "Analysis on photovoltaic panel temperature under the influence of solar radiation and ambient temperature," in 2021 International Conference on Advances in Electrical, Computing, Communication and Sustainable Technologies (ICAECT), pp. 1-5, Bhilai, India, 2021.

[120] A. K. Tripathi, S. Ray, M. Aruna, and S. Prasad, "Evaluation of solar PV panel performance under humid atmosphere," Materials Today: Proceedings, vol. 45, pp. 5916-5920, 2021.

[121] A. Karafil, H. Ozbay, and M. Kesler, "Temperature and solar radiation effects on photovoltaic panel power," Journal of New Results in Science, vol. 5, pp. 48-58, 2016.

[122] P. G. McCormick and H. Suehrcke, "The effect of intermittent solar radiation on the performance of PV systems," Solar Energy, vol. 171, pp. 667-674, 2018.

[123] M. J. Buni, A. A. Al-Walie, and K. A. Al-Asadi, "Effect of solar radiation on photovoltaic cell," International Research Journal of Advanced Engineering and Science, vol. 3, no. 3, pp. 47-51, 2018.

[124] L. Xingcai and N. Kun, "Effectively predict the solar radiation transmittance of dusty photovoltaic panels through Lambert-Beer law," Renewable Energy, vol. 123, pp. 634638, 2018.

[125] P. A. Thorat, A. P. Edalabadkar, R. B. Chadge, and A. Ingle, "Effect of sun tracking and cooling system on photovoltaic panel: a review," Materials Today: Proceedings, vol. 4, no. 14, pp. 12630-12634, 2017.

[126] R. Nasrin, M. Hasanuzzaman, and N. A. Rahim, "Effect of high irradiation on photovoltaic power and energy," International Journal of Energy Research, vol. 42, no. 3, pp. 11151131, 2018.

[127] H. A. Kazem and M. T. Chaichan, "Effect of environmental variables on photovoltaic performance-based on experimental studies," International Journal of Civil, Mechanical and Energy Science (IJCMES), vol. 2, no. 4, pp. 1-8, 2016.

[128] Y. Du, C. J. Fell, B. Duck, D. Chen, K. Liffman, and Y. Zhang, "Evaluation of photovoltaic panel temperature in realistic scenarios," Energy Conversion and Management, vol. 108, pp. 60-67, 2016.

[129] S. Dubey, J. N. Sarvaiya, and B. Seshadri, "Temperature Dependent Photovoltaic (PV) Efficiency and Its Effect on PV Production in the World - A Review," Energy Procedia, vol. 33, pp. 311-321, 2013.

[130] N. H. Zaini, M. Z. Ab Kadir, M. Izadi, N. I. Ahmad, M. A. M. Radzi, and N. Azis, "The effect of temperature on a monocrystalline solar PV panel," in 2015 IEEE Conference on Energy Conversion (CENCON), pp. 249-253, Johor Bahru, Malaysia, 2015.

[131] L. W. Thong, S. Murugan, P. K. Ng, and C. C. Sun, "Analysis of photovoltaic panel temperature effects on its efficiency," System, vol. 18, no. 19, 2016.

[132] V. Perraki and P. Kounavis, "Effect of temperature and radiation on the parameters of photovoltaic modules," Journal of Renewable and Sustainable Energy, vol. 8, no. 1, article 013102, 2016.

[133] P. K. Dash and N. C. Gupta, "Effect of temperature on power output from different commercially available photovoltaic modules," International Journal of Engineering Research and Applications, vol. 5, no. 1, pp. 148-151, 2015.
[134] R. M. Schoeman, A. J. Swart, and C. Pienaar, "Negating temperature on photovoltaic panels," in 2013 Africon, pp. 1-5, Pointe aux Piments, Mauritius, 2013.

[135] A. Idzkowski, W. Walendziuk, and W. Borawski, "Analysis of the temperature impact on the performance of photovoltaic panel," in Photonics Applications in Astronomy, Communications, Industry, and High-Energy Physics Experiments, vol. 9662, Wilga, Poland, 2015.

[136] W. Charfi, M. Chaabane, H. Mhiri, and P. Bournot, "Performance evaluation of a solar photovoltaic system," Energy Reports, vol. 4, pp. 400-406, 2018.

[137] E. B. Ettah, A. B. Udoimuk, J. N. Obiefuna, and F. E. Opara, "The effect of relative humidity on the efficiency of solar panels in Calabar, Nigeria," Universal Journal of Management and Social Sciences, vol. 2, no. 3, pp. 8-11, 2012.

[138] A. Sohani, M. H. Shahverdian, H. Sayyaadi, and D. A. Garcia, "Impact of absolute and relative humidity on the performance of mono and poly crystalline silicon photovoltaics; applying artificial neural network," Journal of Cleaner Production, vol. 276, article 123016, 2020.

[139] A. O. Njok and J. C. Ogbulezie, "The effect of relative humidity and temperature on polycrystalline solar panels installed close to a river," Physical Science International Journal, vol. 20, no. 4, pp. 1-11, 2018.

[140] I. Mesquita, L. Andrade, and A. Mendes, "Effect of relative humidity during the preparation of perovskite solar cells: performance and stability," Solar Energy, vol. 199, pp. 474-483, 2020.

[141] B. G. Burduhos, I. Vişa, A. Duță, and M. Neagoe, “Analysis of the conversion efficiency of five types of photovoltaic modules during high relative humidity time periods," IEEE Journal of Photovoltaics, vol. 8, no. 6, pp. 1716-1724, 2018.

[142] R. T. Hamdi, S. A. Hafad, H. A. Kazem, and M. T. Chaichan, "Humidity impact on photovoltaic cells performance: a review," International Journal of Recent Engineering Research and Development (IJRERD), vol. 3, no. 11, pp. 27-37, 2018.

[143] S. Sengupta, S. Sengupta, C. K. Chanda, and H. Saha, "Modeling the effect of relative humidity and precipitation on photovoltaic dust accumulation processes," IEEE Journal of Photovoltaics, vol. 11, no. 4, pp. 1069-1077, 2021.

[144] W. Javed and B. Guo, "Effect of relative humidity on dust removal performance of electrodynamic dust shield," Journal of Electrostatics, vol. 105, article 103434, 2020.

[145] G. Su, S. Zhang, M. Hu, W. Yao, Z. Li, and Y. Xi, "The modified layer-by-layer weakening solar radiation models based on relative humidity and air quality index," Energy, vol. 239, article 122488, 2022.

[146] M. T. Ahmed, T. Gonçalves, and M. Tlemcani, "Single diode model parameters analysis of photovoltaic cell," in 2016 IEEE International Conference on Renewable Energy Research and Applications (ICRERA), pp. 396-400, Birmingham, UK, 2016.

[147] N. Chatrenour, H. Razmi, and H. Doagou-Mojarrad, "Improved double integral sliding mode MPPT controllerbased parameter estimation for a stand-alone photovoltaic system," Energy Conversion and Management, vol. 139, pp. 97-109, 2017.

[148] M. Kumar and A. Kumar, "Experimental validation of performance and degradation study of canal-top photovoltaic system," Applied Energy, vol. 243, pp. 102-118, 2019.

[149] S. Sarikh, M. Raoufi, A. Bennouna, A. Benlarabi, and B. Ikken, "Photovoltaic system fault identification 
methodology based on IV characteristics analysis," AIP Conference Proceedings, vol. 2123, no. 1, article 020037, 2019.

[150] S. Motahhir, A. El Ghzizal, S. Sebti, and A. Derouich, "Modeling of a photovoltaic system with modified incremental conductance algorithm for fast changes of irradiance," International Journal of Photoenergy, vol. 2018, Article ID 3286479, 13 pages, 2018.

[151] S. Hajighorbani, M. M. Radzi, M. Z. A. Ab Kadir, S. Shafie, R. Khanaki, and M. R. Maghami, "Evaluation of fuzzy logic subsets effects on maximum power point tracking for photovoltaic system," International Journal of Photoenergy, vol. 2014, Article ID 719126, 13 pages, 2014.

[152] H. Mahamudul, M. Saad, and M. Ibrahim Henk, "Photovoltaic system modeling with fuzzy logic-based maximum power point tracking algorithm," International Journal of Photoenergy, vol. 2013, Article ID 762946, 10 pages, 2013.

[153] A. R. Jatoi, S. R. Samo, and A. Q. Jakhrani, “An improved empirical model for estimation of temperature effect on the performance of photovoltaic modules," International Journal of Photoenergy, vol. 2019, Article ID 1681353, 16 pages, 2019.

[154] E. M. Salilih and Y. T. Birhane, "Modeling and analysis of photovoltaic solar panels under constant electric load," Journal of Renewable Energy, vol. 2019, Article ID 9639480, 10 pages, 2019.

[155] R. Lipták and I. Bodnár, "Simulation of fault detection in photovoltaic arrays," Analecta Technica Szegedinensia, vol. 15, no. 2, pp. 31-40, 2021.

[156] K. Ding, J. Zhang, H. Ding, Y. Liu, F. Chen, and Y. Li, "Fault detection of photovoltaic array based on Grubbs criterion and local outlier factor," IET Renewable Power Generation, vol. 14, no. 4, pp. 551-559, 2020.

[157] H. A. Raeisi and S. M. Sadeghzadeh, "A novel experimental and approach of diagnosis, partial shading, and fault detection for domestic purposes photovoltaic system using data exchange of adjacent panels," International Journal of Photoenergy, vol. 2021, Article ID 9956433, 19 pages, 2021.

[158] S. Sharma, M. Pattnaik, M. Sarswat, and L. Varshney, "Comprehension of different techniques used in increasing output of photovoltaic system," in Innovations in Electrical and Electronic Engineering, Lecture Notes in Electrical Engineering, M. N. Favorskaya, S. Mekhilef, R. K. Pandey, and N. Singh, Eds., pp. 203-218, Springer, Singapore, 2021.

[159] S. Saranchimeg and N. K. Nair, "A novel framework for integration analysis of large-scale photovoltaic plants into weak grids," Applied Energy, vol. 282, article 116141, 2021.

[160] D. P. Kothari, A. Pathak, and U. Pandey, "Comparative study of different solar photovoltaic arrays configuration to mitigate the negative impact of partial shading conditions," Journal of Mechanics of Continua and Mathematical Sciences, vol. 16, no. 2, pp. 102-111, 2021.

[161] Y. Muñoz, L. H. Carvajal, J. P. Méndez et al., "Technical and financial assessment of photovoltaic solar systems for residential complexes considering three different commercial technologies and Colombia's energy policy," International Journal of Energy Economics and Policy, vol. 11, no. 2, pp. 272-280, 2021.

[162] M. Z. Zizoui, B. Tabbache, and M. Benbouzid, "Direct power control approach for a grid-connected photovoltaic power system," in Advances in Green Energies and Materials Technology, pp. 295-302, Springer, Singapore, 2021.
[163] N. Ravichandran, H. H. Fayek, and E. Rusu, "Emerging floating photovoltaic system-case studies high dam and Aswan reservoir in Egypt,” Processes, vol. 9, no. 6, p. 1005, 2021.

[164] B. Nayak, A. Mohapatra, and P. Das, "Optimal hybrid array configuration scheme to reduce mismatch losses of photovoltaic system," in 2017 Second International Conference on Electrical, Computer and Communication Technologies (ICECCT), pp. 1-7, Coimbatore, India, 2017.

[165] H. M. Farh and A. M. Eltamaly, "Maximum power extraction from the photovoltaic system under partial shading conditions," in Modern Maximum Power Point Tracking Techniques for Photovoltaic Energy Systems, pp. 107-129, Springer, Cham, 2020.

[166] A. Bidram, A. Davoudi, and R. S. Balog, "Control and circuit techniques to mitigate partial shading effects in photovoltaic arrays," IEEE Journal of Photovoltaics, vol. 2, no. 4, pp. 532546, 2012.

[167] R. Ramaprabha and B. Mathur, "A comprehensive review and analysis of solar photovoltaic array configurations under partial shaded conditions," International Journal of Photoenergy, vol. 2012, 16 pages, 2012.

[168] Y.-J. Wang and P.-C. Hsu, "Analysis of partially shaded PV modules using piecewise linear parallel branches model," World Academy of Science, Engineering and Technology, vol. 60, no. 2, pp. 783-789, 2009.

[169] Y.-J. Wang and P.-C. Hsu, “An investigation on partial shading of PV modules with different connection configurations of PV cells," Energy, vol. 36, no. 5, pp. 3069-3078, 2011.

[170] https://www.slideshare.net/premunknown/solar-designpremkumar1.

[171] K. A. K. Niazi, Y. Yang, and D. Sera, "Review of mismatch mitigation techniques for PV modules," IET Renewable Power Generation, vol. 13, no. 12, pp. 2035-2050, 2019.

[172] A. Minuto, G. Timò, P. Groppelli, and M. Sturm, "Concentrating photovoltaic multijunction (CPVM) module electrical layout optimisation by a new theoretical and experimental "mismatch" analysis including series resistance effects," in 2010 35th IEEE Photovoltaic Specialists Conference, pp. 003081-003086, Honolulu, HI, USA, 2010.

[173] H. Yang, H. Wang, D. Cao, D. Sun, and X. Ju, "Analysis of power loss for crystalline silicon solar module during the course of encapsulation," International Journal of Photoenergy, vol. 2015, Article ID 251615, 5 pages, 2015.

[174] A. D. Dhass, P. Lakshmi, and E. Natarajan, "Analysis of performance degradation parameters of the photovoltaic system in Chennai," International Journal of Pure and Applied Mathematics, vol. 118, no. 20, pp. 439-447, 2018.

[175] L. Ponnusamy and D. Desappan, "An investigation of temperature effects on solar photovoltaic cells and modules," International Journal of Engineering, vol. 27, no. 11(B), pp. 1713-1722, 2014. 